\title{
EFFECT OF HIGH PRESSURE ON MOISTURE AND NaCl DIFFUSION INTO TURKEY BREAST
}

\author{
A Thesis \\ Presented in Partial Fulfillment of the Requirements for \\ the Degree of Master of Science in the \\ Graduate School of The Ohio State University
}

By

María Fernanda Villacís Barrazueta

The Ohio State University

2006

Master's Examination Committee:

Dr. V. M. Balasubramaniam, Adviser

Dr. S. K. Sastry

Dr. J. Litchfield

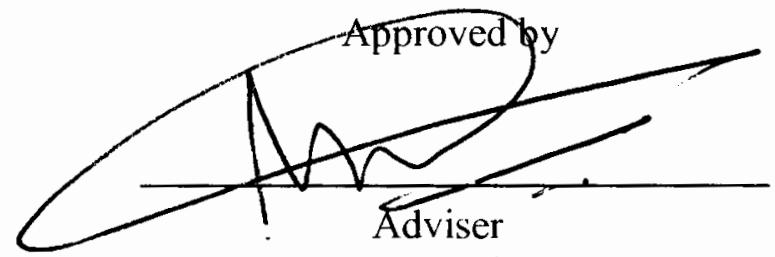

Food Science and Nutrition Graduate Program 


\begin{abstract}
High pressure processing (HPP) has shown to affect the mass transfer of components into food. The effect of pressure (0.1-300 MPa) on the diffusion of $\mathrm{NaCl}$ and water into turkey breast meat processed at $25^{\circ} \mathrm{C}$ was evaluated. Turkey sample suspended at $50 \mathrm{~g} / \mathrm{L} \mathrm{NaCl}$ solution held at $25^{\circ} \mathrm{C}$ served as control. $\mathrm{NaCl}$ and water diffusion were found to be a function of pressure and holding time. During the pressure come-up-time diffusion of both water and $\mathrm{NaCl}$ into turkey breast was enhanced as compared to control. At $150 \mathrm{MPa}$, the sample moisture diffusion coefficient was found to be minimal, while $\mathrm{NaCl}$ diffusion coefficient was maximum. Application of pressure, $\mathrm{NaCl}$ and water diffusion altered meat textural properties. Hardness, gumminess and chewiness of sample increased with pressure holding time and were minimal at $150 \mathrm{MPa}$. Cohesiveness was not affected with pressure application, but was found to increase with holding time. Examination of meat ultrastructure revealed that $150 \mathrm{MPa}$ pressure treatment resulted in swelling of myofibrils, disappearance of the M-line, reduced difference in the density of the A-band and I-band and breaking of segments of Z-line. However, the myofibrils structure was intact, which led to the increased water holding capacity. HPP could be a useful technique for the salting of turkey breast meat, which may help in reducing the processing time as improving the textural properties.
\end{abstract}


Dedicated to my parents Johnny Villacís and Celeste Barrazueta, my sisters -Ximena and Lorena, and my brothers - Juanjo and Marcelo 


\section{ACKNOWLEDGMENTS}

This thesis is the result of two years of work whereby I have been accompanied and supported by many people. I wish to express my gratitude to everyone who contributed to the contents of this thesis.

I am grateful to my advisor, Dr. V. M. Balasubramaniam for providing me the remarkable opportunity of a fulfilling graduate learning experience through this research and his advising. I am thankful to my committee members: Dr J. Litchfield and Dr. S. K. Sastry for their valuable inputs.

I would like to thank to Dr. N. K. Rastogi for his insightful comments and helpful advice. I am grateful to Chitra Kusnadi for her guiding in the use of Matlab and Kathy Wolken for her valuable help for obtaining the TEM images.

To my beloved friends and the entire lab group for their endless support and encouragement through out my stay at Columbus, I owe special thanks.

I am forever indebted to my family for their endless and permanent understanding, patience and encouragement.

Finally, I would like to thank to Fulbright-LASPAU Fellowship and The Ohio State University Graduate School for their financial support. 


\section{VITA}

October, 26, 1979

Born - Quito, Ecuador

2004

Food Engineering,

Universidad Técnica de Ambato,

Ambato, Ecuador

2004-present

Graduate Research Associate, The

Ohio State University

\section{FIELD OF STUDY}

Major Field: Food Science and Nutrition 


\section{TABLE OF CONTENTS}

Abstract .......... Page

\section{Chapters}

1. Introduction

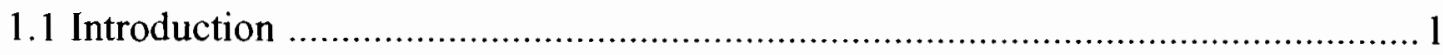

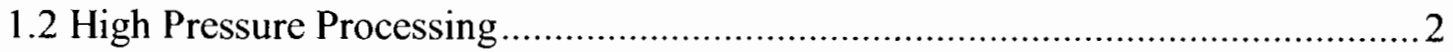

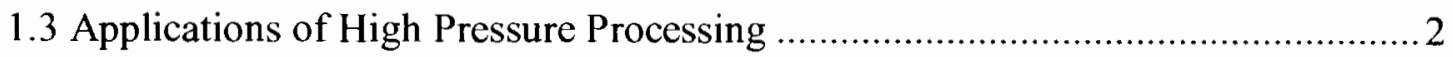

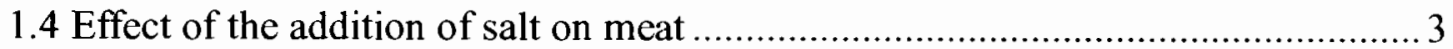

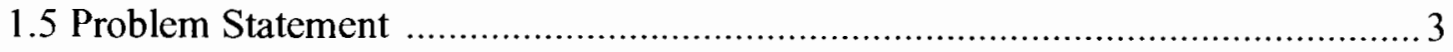

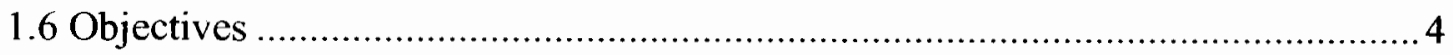

2. Review of Literature 


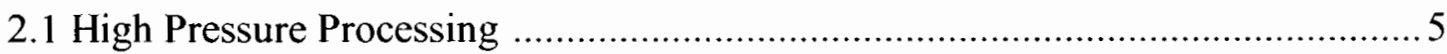

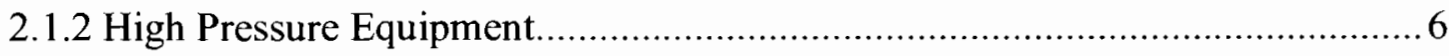

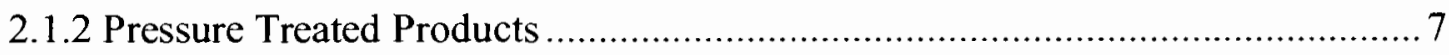

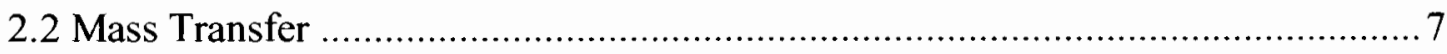

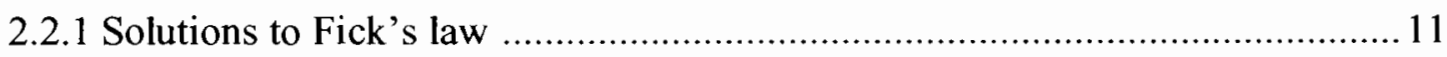

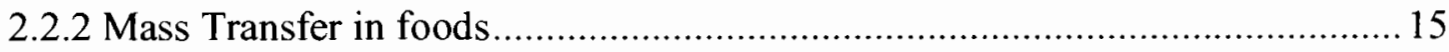

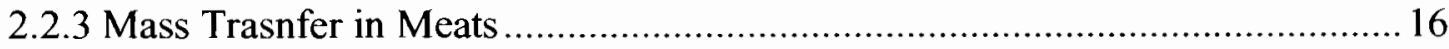

2.2.4 Mass Transfer during advanced thermal and nonthermal processes................ 19

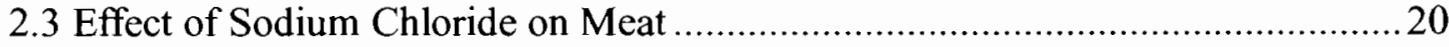

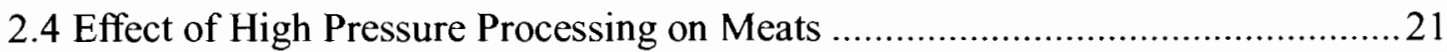

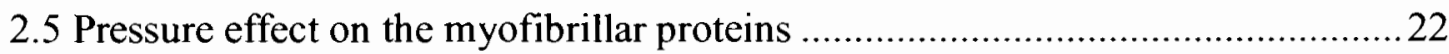

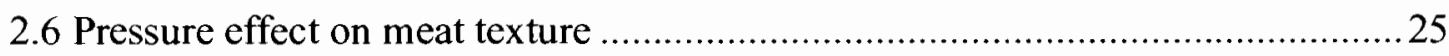

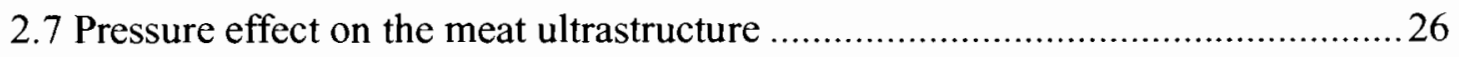

3. Effect of High Pressure on Moisture and $\mathrm{NaCl}$ Diffusion into Turkey Breast

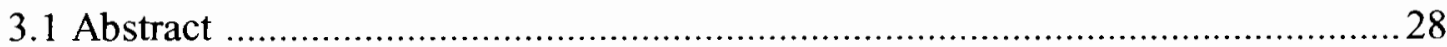

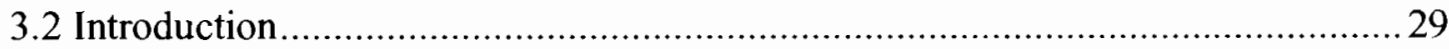

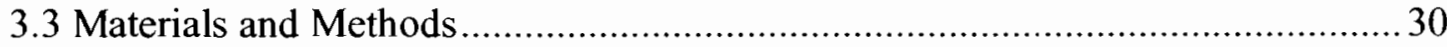

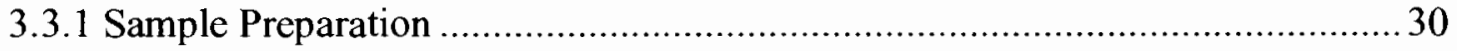

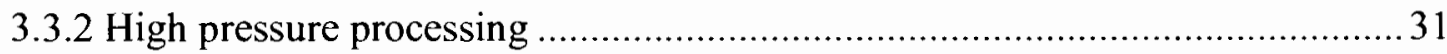

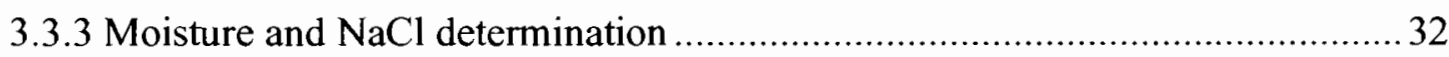

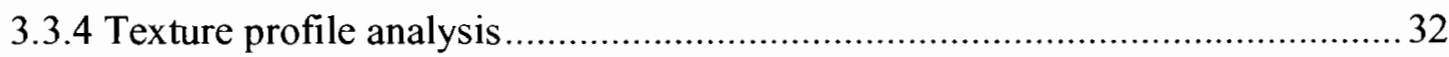

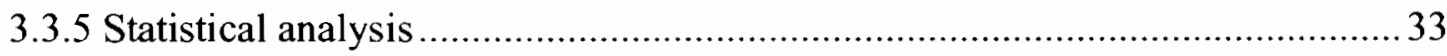




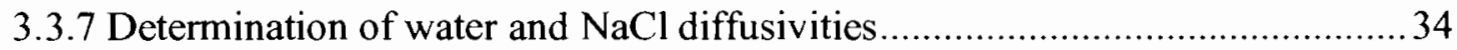

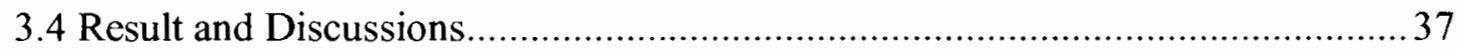

3.4.1 Salting of turkey breast at atmospheric pressure ….................................... 37

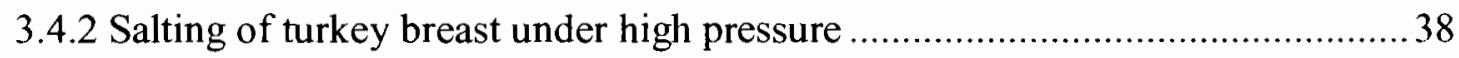

3.4.3 Effect of high pressure treatment on textural properties..................................40

3.4.4 Effect of high pressure treatment on ultrastructure ...................................... 41

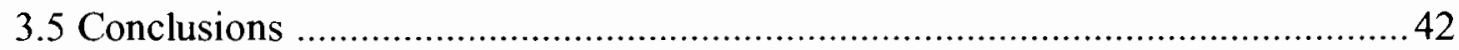

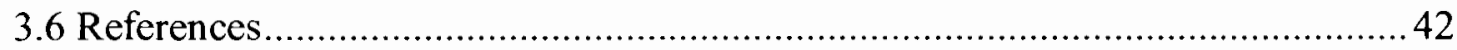

4. Conclusions and future recommendations

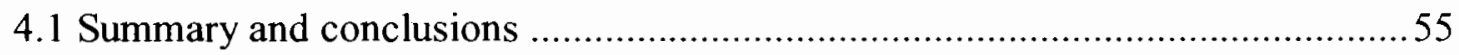

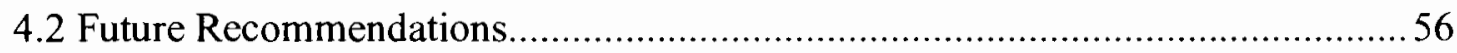

Appendix

A. Matlab program for the calculation of $\mathrm{q}_{\mathrm{n}}$ and $\mathrm{C}_{\mathrm{n}}$ (Eqns. (4) \&(5) ....................57

B. Matlab for program for the calculation of $m_{\infty}$ or $s_{\infty}$ and $k_{m}$ or $k_{s} \ldots \ldots \ldots \ldots \ldots \ldots \ldots . .59$

C. Texture Properties for Pressure and Non-pressure treated turkey breast samples

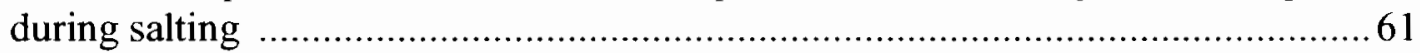

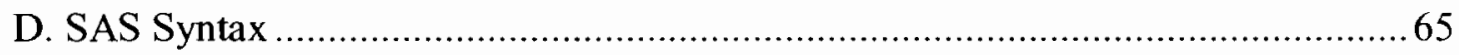

E. TEM of Pressure treated turkey breast samples ...........................................67 


\section{LIST OF TABLES}

Table

2.1 Commercially available pressure treated products

2.2 Examples of mass diffusivity coefficients in food systems

3.1 Effective diffusion coefficients of water $\left(\mathrm{D}_{\mathrm{ew}}\right)$ and $\mathrm{NaCl}\left(\mathrm{D}_{\mathrm{es}}\right)$ at different pressures

C.1 Hardness $(\mathrm{N})$ of pressure treated and non-treated $(0.1 \mathrm{MPa})$ turkey breast samples during salting

C.2 Springiness $(\mathrm{mm})$ of pressure treated and non-treated (0.1 MPa) turkey breast samples during salting

C.3 Cohesiveness of pressure treated and non-treated $(0.1 \mathrm{MPa})$ turkey breast samples during salting

C.4 Chewiness $(\mathrm{Nmm})$ of pressure treated and non-treated $(0.1 \mathrm{MPa})$ turkey breast samples during salting

C.5 Guminess $(\mathrm{N})$ of pressure treated and non-treated $(0.1 \mathrm{MPa})$ turkey breast samples during salting 


\section{LIST OF FIGURES}

Figure

Page

2.1 Simplified Schematic diagram of a high pressure processor …......................... 8

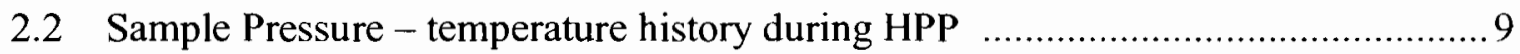

2.3 Diffusion of particles from a plane sheet in an enclosed chamber ...................... 13

2.4 Element of volume used for mass transfer determination ................................. 15

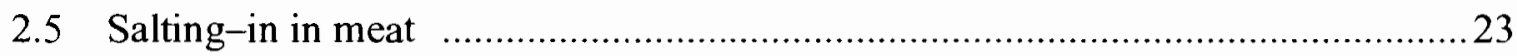

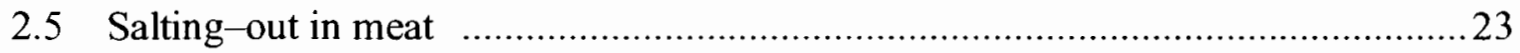

3.1 Theoretical diffusion curve for cubical configuration as per Eqs. (3) and (4) .......48

3.2 Variation of moisture and $\mathrm{NaCl}$ content during salting of turkey breast at atmospheric pressure with treatment time

3.3 Effect of pressure come up time on moisture and $\mathrm{NaCl}$ content during salting of turkey breast at different pressures 50

3.4 Variation of moisture and $\mathrm{NaCl}$ content with holding time during high pressure processing of turkey breast sample

3.5 Effect of Pressure on hardness, cohesiveness, springiness, chewiness, and gumminess of turkey breast pieces

3.6 TEM of control and pressure treated turkey breast sample during salting at various pressures $(0.1 \mathrm{MPa}, 150 \mathrm{MPa}$, and, $300 \mathrm{MPa})$

E. 1 TEM of pressure treated turkey breast samples during salting at $150 \mathrm{MPa}$ and $300 \mathrm{MPa}$ for $0.1 \mathrm{~s}$ and without salting at $150 \mathrm{MPa}$ for 15 minutes .68 


\section{CHAPTER I}

\section{INTRODUCTION}

\subsection{Introduction}

During the last decade, high pressure processing (HPP) has emerged as one of the commercially viable technologies to produce safe foods with fresh-like characteristics. This has given the industry the opportunity not only of producing products with better quality, but also of exploring processing new products which are otherwise difficult if not impossible to process. However, some of the effects of HPP to foods are not completely understood, especially those concerning transport phenomena (heat transfer, mass transfer). Mass transfer in foods is affected by product and process related factors. The product related factors include shape, size, composition, structure of the food, chemical and structural changes in the food during the process, among others. Since food is a complex heterogeneous material, these factors vary widely among different food materials; and thus determination of the mass transfer is a complex process.

Knowing how the diffusion occurs in food facilitates the process design as well as control of relevant unit operations. Addition of substances such as salt, phosphates, seasonings, among others to meat products has been done in the industry in order to incorporate flavor and improve the texture of the products. This is done by soaking the 
meat in the mass transfer solution for several hours (still-marination). Alternatively it may be possible to tumble the meat in the solution or inject solution within the meat. Some of these processes may take long time and may increase of the risk for contamination.

\subsection{High Pressure Processing}

Although the possibility of using HPP to inactivate food microorganisms was known since the $19^{\text {th }}$ century, this technology has been commercially used only during the last two decades. Increased consumer demand for food products with a high quality, fresh tasting properties as well as improved equipment capability facilitated this development. High-pressure food pasteurization use a pressure level around 400-600 MPa with or without heat. Sterilization implies the use of elevated pressures (>500 MPa) and high temperatures $\left(90-120^{\circ} \mathrm{C}\right)$. Most of the treatments require 3 to 10 minutes processing holding time. The application of these levels of pressure, temperature and time could cause alterations in the structure of the food which also would affect the transfer mechanisms.

\subsection{Application of High Pressure Processing}

Currently, the principal goal for the utilization of HPP is the production of fresh-like, microbiologically safe products. Products already available in the commercial market include guacamole, fruit jellies, jam, fruit juices, ice cream, salad dressings, salsa, rice products, seafood such as shucked oyster meat, and meat products such as tenderized meat, pork sausages, among others. From early studies, it is known that HPP can enhance 
the osmotic dehydration of several fruits and vegetables. However, chemical and physical alterations into the food due to the application of high pressures may affect the diffusion process and the diffusion rates.

\subsection{Effect of the addition of salt on meat}

Sodium chloride is added to meat with different purposes and in different ways. $\mathrm{NaCl}$ can be added by immersing the meat in highly concentrated (>5M) $\mathrm{NaCl}$ solutions producing the elimination of water from the tissue and the incorporation of $\mathrm{NaCl}$. This lowers the water activity extending the shelf life of that meat. Another way is the incorporation of brine into the meat. Relatively low concentration solutions $(\leq 1.5 \mathrm{M})$, brines, are added to meat, enhancing the moistness and juiciness of the product by increasing the water holding capacity of the myofibrils in the tissue. However, different technologies have different impact on the tissue structure modifying the water holding capacity.

\subsection{Problem Statement}

Currently limited literature is available to characterize the mass transfer in different substances subjected to pressure treatment. Food products could go through cell damage when pressurized, which could alter the diffusion behavior. Further, chemical and structural changes facilitated because of the presence of the diffusing substance or the high pressure application may significantly alter the diffusion rate. Thus, in order to design different process under this new technology, it is necessary to investigate the effect of HPP on the diffusion of compounds in food under controlled process conditions. 
Recently, the meat industry has been interested in using HPP to produce meat products. In order to produce meat products under this technology, it is necessary to understand and be acquainted with the characteristics of the different involved mechanisms under different conditions of pressure, time and temperature. Brining of meat by traditional methods (atmospheric pressure still-marination, tumbling) leads to a process which can take several hours.

\subsection{Objectives}

This research was conducted with the following objectives:

- Determine the effect of high pressure processing on the water and salt diffusion into turkey breast muscle

- Calculate effective diffusion coefficients during high pressure processing of meat samples

- To study the textural changes in the turkey muscle suspended in brine solution subjected to high pressure processing. 


\section{CHAPTER 2}

\section{REVIEW OF LITERATURE}

\subsection{High Pressure Processing}

High pressure processing is an alternative preservation technology that can be used for food pasteurization and sterilization. The technology has been demonstrated to reduce the number of microorganisms, destroy pathogens and inactivate deteriorative enzymes, extend shelf life while maintaining product quality attributes such as color, texture, and flavor in most food products (Fellows, 2000; Knorr, 1999). During HPP, the food material is typically pre-packaged, and subjected to pressures (100-800 MPa) with or without addition of heat.

The basic principles of high pressure processing process are (Earnshaw, 1996):

- Le Chatelier's principle which states that, under equilibrium conditions, a process which involves the increase in the pressure will favor those changes involving a decrease in volume.

- Isostatic principle which states that pressure is transmitted in a uniform and quasi-instantaneous manner throughout the whole product.

The advantages of using high pressure processing are: 
- Shelf life extension is typically three times longer than thermally processed foods for high-acid foods (Polydera, Stoforos, \& Taoukis, 2003) and two times longer for low-acid foods (Ramirez-Suarez, J. C., \& Morrisey, M. T., 2006);

- Minimal effect on texture, fresh flavor and high quality;

- Rapid process; pressure accelerates microbial inactivation rates.

- High consumer acceptance

The limitations of using high pressure processing are (Earnshaw, R. 1996):

- High cost, low throughput

- Variable effect on enzymes and,

- Batch process $\&$ low throughput

\subsubsection{High Pressure Equipment}

Industrial scale high-pressure equipment is available either as batch or semicontinuous systems (Knorr, 1999). While pumpable products can be processed in a semicontinuous system, batch systems can be used for processing both solid and liquid prepackaged products. Pre-packed food products are loaded into a basket and placed inside the pressure vessel (Fig 2.1). The vessel capacity ranges from few milliliters for research scale equipment to 600 liters for commercial scale production equipment. The vessel is filled with pressure transmitting fluid (water or oil based solution). The chamber is closed with help of the upper closure and pressurized with the intensifier pump. The desired pressure is maintained for the targeted holding time to be immediately decompressed. After decompression, the vessel is open and the food unloaded (Balasubramaniam, Ting, Stewart \& Robbins, 2004). 
Temperature, pressure and process holding time are controlled for each cycle. Because of the compression heating, product temperature increases with pressure (Fig 2.2). Temperature is maintained during the holding time if there is no heat loss to the environment. Holding time vary from $5-10$ minutes depending of the product and the goal of the process. During depressurization the product temperature falls back close to its initial temperature.

\subsubsection{Pressure treated products}

High pressure pasteurized products are commercially available in USA, Europe, Japan, Australia and Mexico and Canada. Wide range of product categories including fruits and vegetables, sea-food, ready-to-eat meats, juices, and dairy products are pressure treated. Table 2.1 shows examples of high pressure processed products available in various part of the world

\subsection{Mass Transfer}

Mass transfer in foods has been extensively studied because it helps to predict, control, and design processes which involve the movement of components from one part of a system to another. Mass transfer plays an important role in a number of unit operations such as dehydration, extraction, smoking, baking, frying, drying, distillation, membrane separation, and absorption. Mass transfer may also be involved in a number of other processes such as salting, sugaring, deaeration, crystallization etc. 


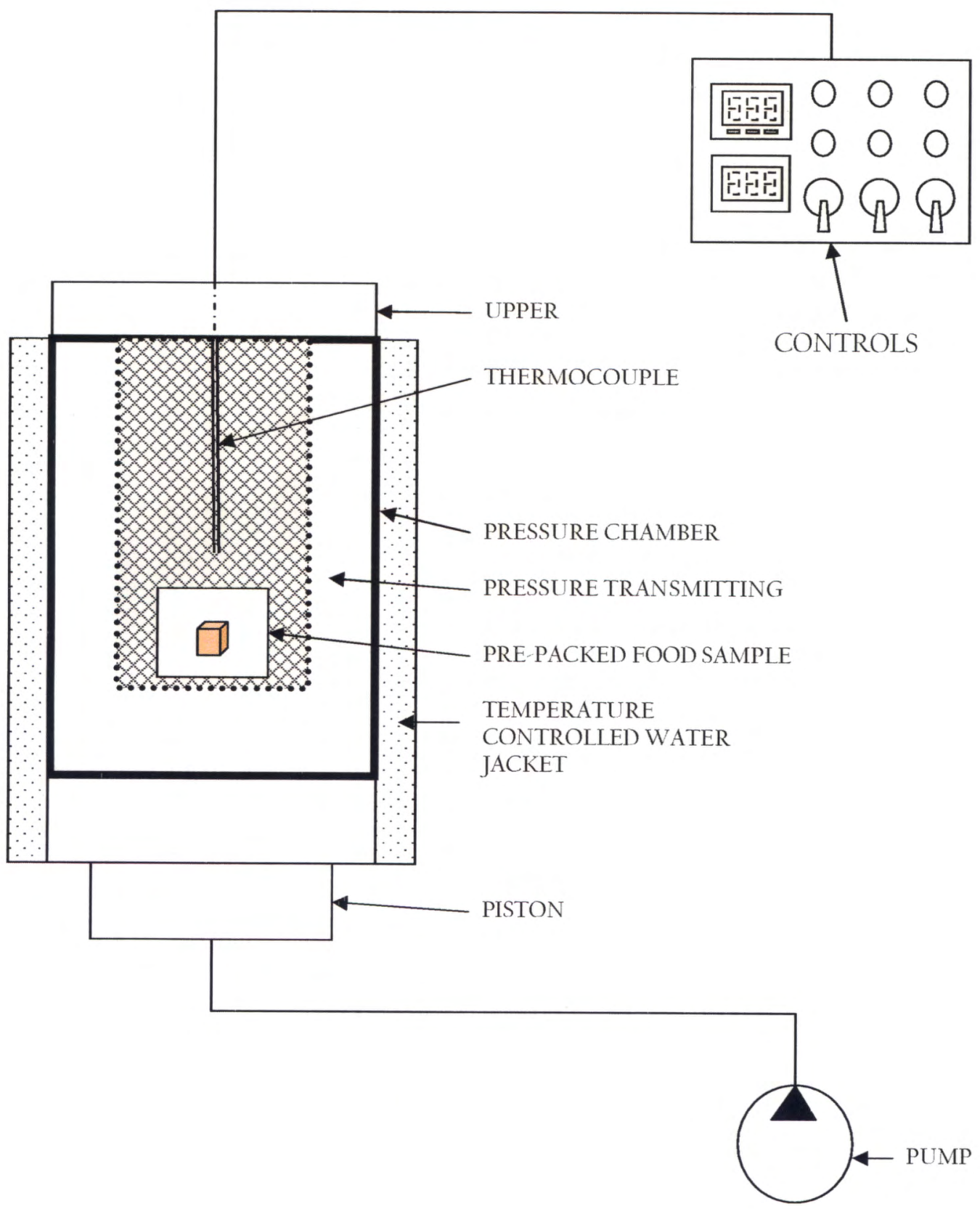

Figure 2.1: Simplified Schematic diagram of a high pressure processor. 


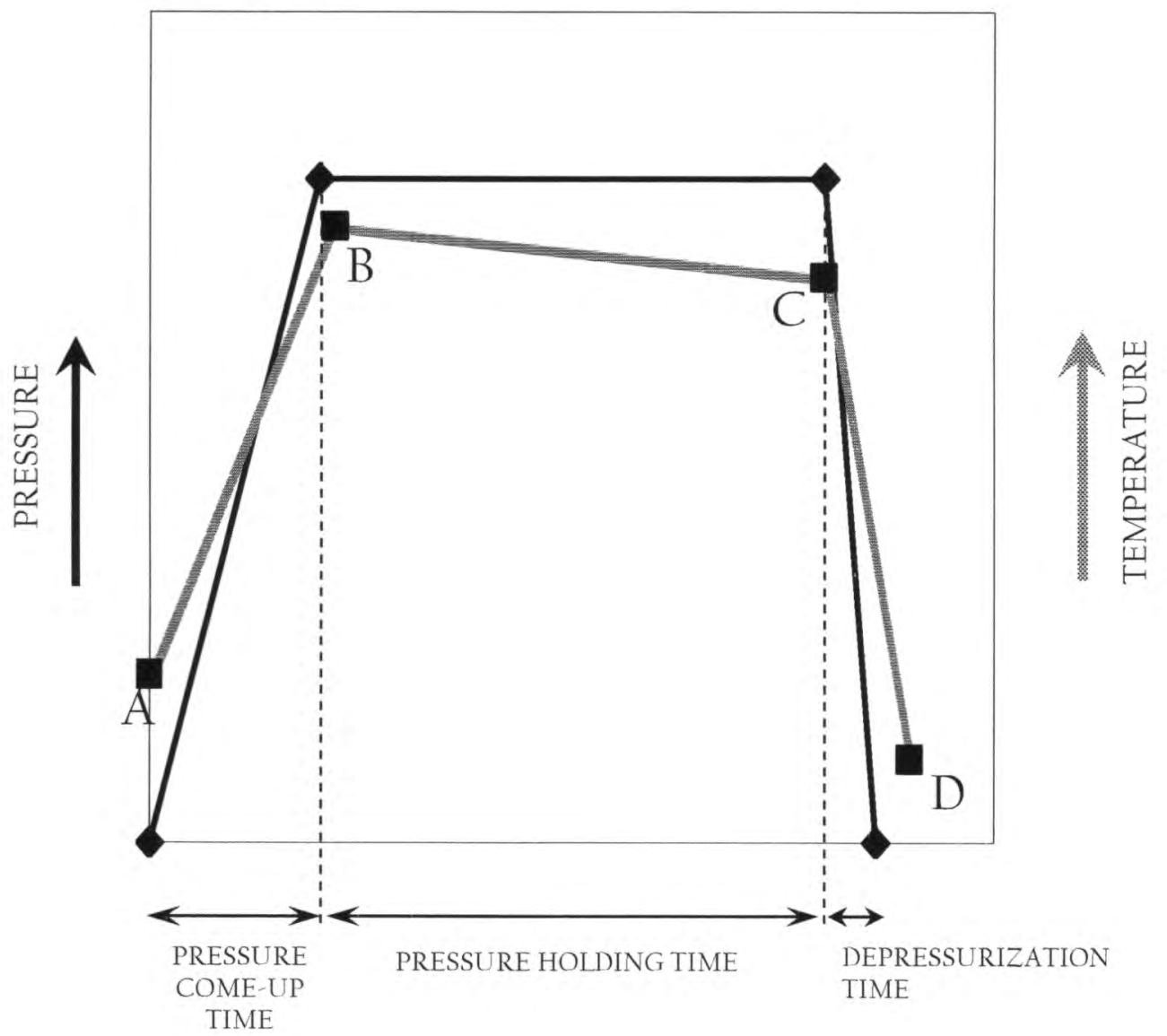
A: Initial product temperature
B: Temperature after pressurization
C: Temperature before pressurization
D: Temperature after depressurization

Figure 2.2: Sample Pressure - Temperature history during HPP. 


\begin{tabular}{|c|c|c|c|c|c|}
\hline $\begin{array}{c}\text { Country } \\
\text { (year) }\end{array}$ & Product & Process & Packaging & Shelf-life & $\begin{array}{l}\text { Achievements of HPP } \\
\text { \& comments }\end{array}$ \\
\hline $\begin{array}{l}\text { Spain } \\
(1998)\end{array}$ & $\begin{array}{c}\text { Delicatessen: } \\
\text { Cooked sliced } \\
\text { ham and "tapas" } \\
\text { (pork and } \\
\text { poultry cuts) }\end{array}$ & $\begin{array}{l}400 \mathrm{MPa} \\
10 \mathrm{~min} \\
\text { at } 8^{\circ} \mathrm{C}\end{array}$ & $\begin{array}{l}\text { Darfresh } \\
\text { vacuum- } \\
\text { packed and } \\
\text { gas-packed }\end{array}$ & 2 months & $\begin{array}{l}\text { Sanitization without } \\
\text { color and taste } \\
\text { modifications }\end{array}$ \\
\hline $\begin{array}{l}\text { USA } \\
(2001)\end{array}$ & $\begin{array}{l}\text { Cooked sliced } \\
\text { ham, pork meat } \\
\text { products and } \\
\text { Parma ham }\end{array}$ & & $\begin{array}{l}\text { Vacuum- } \\
\text { packed }\end{array}$ & & $\begin{array}{l}\text { Sanitization without } \\
\text { color and taste } \\
\text { modifications. Listeria } \\
\text { destruction. }\end{array}$ \\
\hline $\begin{array}{l}\text { USA } \\
(2001)\end{array}$ & $\begin{array}{l}\text { Poultry ready-to- } \\
\text { eat products }\end{array}$ & & $\begin{array}{l}\text { Gas-packed } \\
\text { plastic } \\
\text { pouches }\end{array}$ & & $\begin{array}{l}\text { Sanitization without } \\
\text { color and taste } \\
\text { modifications. Listeria } \\
\text { destruction. }\end{array}$ \\
\hline $\begin{array}{l}\text { USA } \\
(2002)\end{array}$ & $\begin{array}{c}\text { Spicy sliced } \\
\text { precooked } \\
\text { chicken and beef } \\
\text { for fajitas }\end{array}$ & & $\begin{array}{l}\text { Vacuum- } \\
\text { packed }\end{array}$ & 21 days & $\begin{array}{l}\text { Sanitization without } \\
\text { color and taste } \\
\text { modifications. Listeria } \\
\text { destruction. The Fajitas } \\
\text { kit is made of HPP meat } \\
\text { but also HPP onions, } \\
\text { peppers and guacamole. }\end{array}$ \\
\hline $\begin{array}{l}\text { Spain } \\
(2002)\end{array}$ & $\begin{array}{l}\text { Thick sliced } \\
\text { ham, chicken } \\
\text { and turkey } \\
\text { products }\end{array}$ & $\begin{array}{l}500 \mathrm{MPa} \\
4 \text { to } 10 \\
\min \\
\text { at }+8^{\circ} \mathrm{C}\end{array}$ & $\begin{array}{l}\text { Vacuum } \\
\text { packed } \\
\text { Darfresh }\end{array}$ & $\begin{array}{l}2 \text { months for } \\
\text { cooked } \\
\text { products }\end{array}$ & $\begin{array}{l}\text { Sanitization without } \\
\text { color modifications. } \\
\text { Listeria destruction. } \\
\text { Increase of shelf-life and } \\
\text { additives reduction. }\end{array}$ \\
\hline $\begin{array}{l}\text { Italy } \\
(2003)\end{array}$ & $\begin{array}{l}\text { Porma ham } \\
\text { (Prosciutto), } \\
\text { salami, } \\
\text { mortadela }\end{array}$ & $\begin{array}{l}600 \mathrm{MPa} \\
10 \mathrm{~min} \\
\text { at }+7^{\circ} \mathrm{C}\end{array}$ & $\begin{array}{l}\text { Vacuum- } \\
\text { packed }\end{array}$ & & $\begin{array}{l}\text { Sanitization without } \\
\text { color and taste } \\
\text { modifications. Listeria } \\
\text { destruction. Increase of } \\
\text { shelf-life. Products for } \\
\text { USA and Japan exports. }\end{array}$ \\
\hline $\begin{array}{l}\text { Japan } \\
(2005)\end{array}$ & $\begin{array}{l}\text { Cooked pork } \\
\text { meta products } \\
\text { nitrites-free: } \\
\text { ham, sausages } \\
\text { and bacon }\end{array}$ & $\begin{array}{l}600 \mathrm{MPa} \\
5 \mathrm{~min} \text { at } \\
+5^{\circ} \mathrm{C}\end{array}$ & $\begin{array}{l}\text { Vacuum- } \\
\text { packed }\end{array}$ & & $\begin{array}{c}\text { Sanitization. Increase of } \\
\text { shelf-life. }\end{array}$ \\
\hline $\begin{array}{l}\text { Germany } \\
(2005)\end{array}$ & $\begin{array}{l}\text { Smoked German } \\
\text { ham: whole } \\
\text { sliced and diced } \\
\text { products }\end{array}$ & $\begin{array}{l}600 \mathrm{MPa} \\
2 \mathrm{~min} \text { at } \\
+5^{\circ} \mathrm{C}\end{array}$ & $\begin{array}{l}\text { Vacuum- } \\
\text { packed }\end{array}$ & & $\begin{array}{l}\text { Sanitization. Listeria } \\
\text { destruction. Products for } \\
\text { USA export. }\end{array}$ \\
\hline $\begin{array}{l}\text { USA } \\
(2005)\end{array}$ & $\begin{array}{l}\text { Deli meats, } \\
\text { sliced meat } \\
\text { products. }\end{array}$ & & & $\begin{array}{l}120 \text { days } \\
\text { under } \\
\text { refrigeration }\end{array}$ & $\begin{array}{l}\text { Sanitization. Reduction } \\
\text { of sodium, and additives }\end{array}$ \\
\hline
\end{tabular}

Table 2.1. Commercially available pressure treated products (Source: 
In many food process operations, mass transfer is usually the rate limiting factor compared to heat transfer. Diffusion is a mass transfer process and can be defined by the migration of a system component from one part to another due to a concentration gradient (Singh \& Heldman, 2001; Crank, 1975).

\subsubsection{Solutions to Fick's law}

Diffusion phenomena under diverse conditions can be described by mathematical models based on Fick's second law, which defines the diffusion for unidirectional unsteady state (Crank, 1975; Rastogi, Raghavaro, Niranjan \& Knorr, 2002):

$$
\frac{\partial C}{\partial t}=D \frac{\partial^{2} C}{\partial x^{2}}
$$

Where $C$ is the concentration of diffusing substance, $x$ the space coordinate measured normal to the section, and $D$ is the diffusion coefficient.

Solutions for steady and unsteady states of diffusion are available considering one or more directions and different shapes of the solid material (Crank, 1975). Solutions have been proposed for different solids shapes such as infinite flat plate, rectangular parallelepiped, and finite cylinder. Lerici, Pinnavaia, Dalla Rosa, and Bartolucci (1985) evaluated the influence of the shape in the osmotic dehydration of apple pieces. Sticks, slices, cubes and ring shapes were evaluated giving different values for each of them.

Crank (1975) provided mathematical solutions for diffusion equation to estimate diffusion coefficients during different scenarios. Consider the case of diffusion of solute from a stirred solution of limited volume to a plane sheet. Assume that the solution is 
well stirred, concentration of solute in the solution depends on the time and the total amount of solute in the solution and sample remains constant during the diffusion; Crank (1975) suggested the following solution:

If $x=0$ at the center at $t=0$ (initial condition, Fig. 3.a.):

$\mathrm{C}=\mathrm{Co}$ : initial concentration of the solute in the sheet at $-l \leq x \leq l$

with the boundary conditions

$$
\begin{aligned}
& \frac{\partial C}{\partial t}=0 \text { at } x=0 \text { for all } t \\
& \alpha l \frac{\partial C}{\partial t}=D \frac{\partial C}{\partial x} \text { at } x= \pm l \text { when } \mathrm{t}>0
\end{aligned}
$$

Where $l$ is the half thickness of the sheet, $\alpha$ is the ratio of the volumes of solution and the sheet $(\alpha=a / l)$, and $a$ is the extension of the space occupied by the solution.

The solution for the above conditions has been solved by Crank (1975), and presented the following equation for diffused solute ratio, $\mathrm{M}_{\mathrm{r}}$ :

$$
M_{r}=\frac{\left(m_{t}-m_{\infty}\right)}{\left(m_{0}-m_{\infty}\right)}=\sum_{n=1}^{\infty} C_{n} \exp \left[-D q_{n}^{2} t / l^{2}\right]
$$




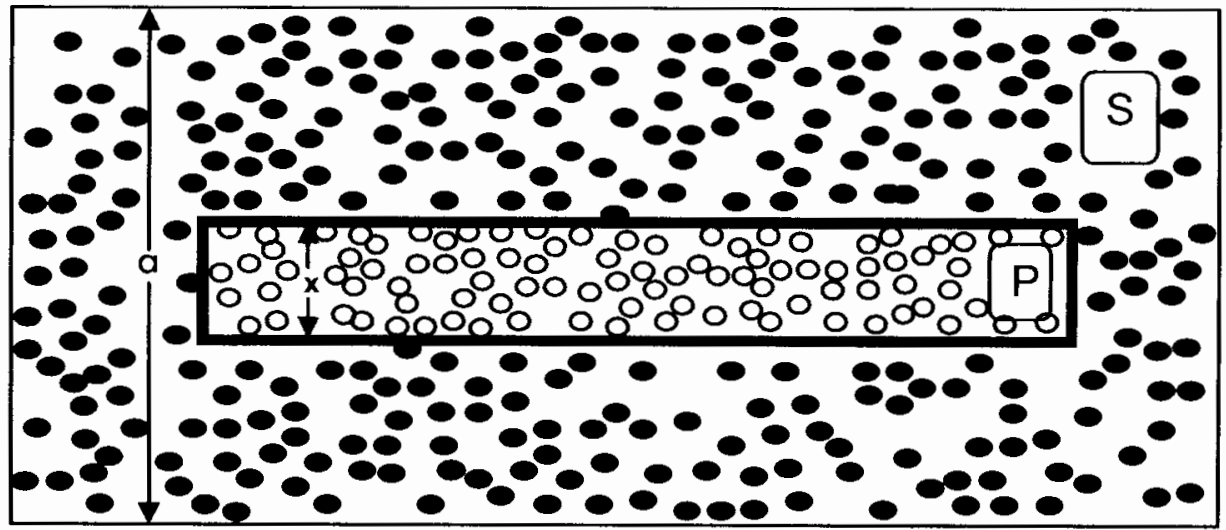

(a)

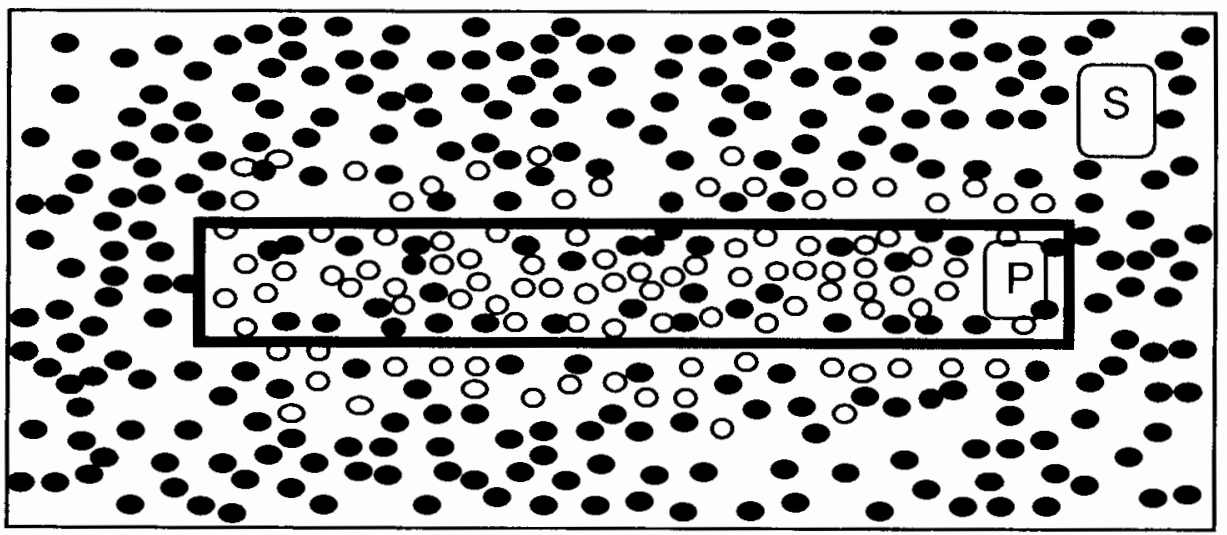

(b)

Figure 2.3. Diffusion of particles to and from a plane sheet in an enclosed chamber. (a) Initial condition before diffusion. (b) During diffusion. S: Diffusing solution. P: Plane sheet. 
Where $m$ is the solute content; the subscripts $0, \infty$, and $t$ represent the initial, equilibrium and concentrations at any-time $\mathrm{t}$ respectively; $\mathrm{D}$ is the effective diffusivity of the solute; the $q_{n}$ 's are the non-zero positive roots of:

$\tan q_{n}=-\alpha q_{n}$.

and

$\mathrm{C}_{\mathrm{n}}=\frac{2 \alpha(1+\alpha)}{\left(1+\alpha+\alpha^{2} \mathrm{q}_{\mathrm{n}}^{2}\right)}$

Rastogi and Raghavaro (2004) developed a solution for a rectangular parallelepiped of sides $2 \mathrm{a}, 2 \mathrm{~b}$ and $2 \mathrm{c}$, giving the equation:

$M_{r}=\frac{\left(m_{t}-m_{\infty}\right)}{\left(m_{0}-m_{\infty}\right)}=\sum_{n=1}^{\infty} C_{n}^{3} \exp \left[-D q_{n}^{2} t\left(\frac{1}{a^{2}}+\frac{1}{b^{2}}+\frac{1}{c^{2}}\right)\right]$

If all the sides of the parallelepiped are equal $(2 a=2 b=2 c)$, the solution is reduced to a cubical configuration (Rastogi et al., 2004)

$$
M_{r}=\frac{\left(m_{1}-m_{\infty}\right)}{\left(m_{0}-m_{\infty}\right)}=\sum_{n=1}^{\infty} C_{n}^{3} \exp \left[-D q_{n}^{2} t\left(\frac{3}{a^{2}}\right)\right]
$$




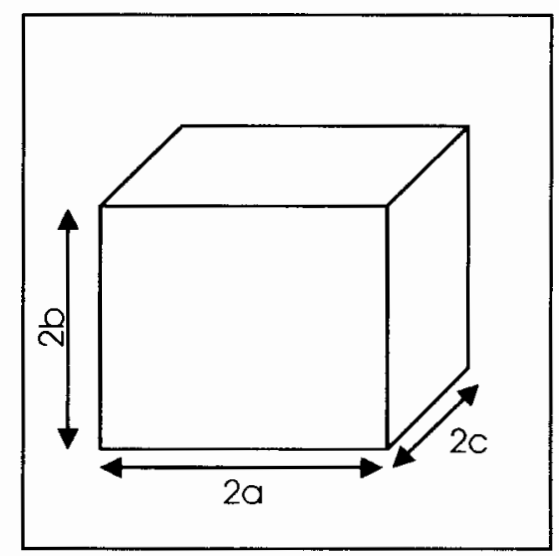

Fig. 2.4. Element of volume used for mass transfer determination

\subsubsection{Mass Transfer in foods}

Different factors affect the mass transfer in a system. The presence of agitation during the process accelerates diffusion rate (Oztan \& Mehmet, 2005). The concentration of solute in the diffusing solution affects significantly the diffusion behavior. Different concentrations have been considered in studies (Nicoletti, Romanelli, Gabas \& Romero, 2003; Ünal, Erdoghdu, Ekiz, \& Ozdemir, 2004; Rastogi et al., 2004). Higher the concentration in the diffusing solution the faster the diffusion due to presence of concentration gradient between the two phases of the system. Likewise, the temperature alters the diffusion coefficients. In processes such as osmotic dehydration, it is expected that diffusion is greater when the temperature is higher (Rastogi et al., 2002); however in some other processes the utilization of high temperatures also involved chemical changes in the food which could slow down the diffusion of a solute on it (Ahromrit, Ledward, and Niranjan, 2006). Since the mass transfer occurs through the surface area exposed to the solution, the food size and shape also plays an important role. Diffusion process time 
increases with sample size as it dependant upon diffusion path length. $\mathrm{pH}$ and presence of other solutes can also influence diffusion.

\subsubsection{Mass Transfer in Meats}

Salting, marination, drying are some of the common examples for mass transfer in meats. During drying there is a loss in the moisture content of the meat. The effective moisture diffusivity coefficient has been calculated for pork ham during drying (Gou, Comaposada \& Arnau, 2004). Gou et al. (2004) stated that the effective moisture diffusivity coefficient was affected by the process temperature and $\mathrm{NaCl} /$ moisture gradient. Several researchers estimated mass diffusion coefficients of various compounds from water based solutions to meat samples at atmospheric pressure (Oztan et al., 2004; Gou, Comaposada \& Arnau, 2003; Unal et al., 2004; Wang, Tang \& Correa, 2000). Graiver, Pinotti, Califano, and Zaritzy (2006) studied the effect of the sodium chloride concentration in the brining solution on the direction of the mass transfer. Authors reported that low concentration of sodium chloride $(<10 \%)$ resulted in diffusion of water and salt from the solution to the meat, known as salting-in. On the other hand, for high salt concentrations, salt diffused from the solution into meat while water diffused out from the meat to the solution. This process is called as salting-out.

Graiver et al. (2006) calculated the $\mathrm{NaCl}$ diffusivity coefficients as $6.0 \times 10^{-10}$ $\mathrm{m}^{2} / \mathrm{s}$ when a $3 \% \mathrm{NaCl}$ solution was used. A similar study using Pantanal caiman muscle considered the effect of temperature, initial brine concentration and brine/muscle ratio on the diffusivity values of $\mathrm{NaCl}$ (Nicoletti et al., 2003). At $20^{\circ} \mathrm{C}$, with $15 \%(\mathrm{w} / \mathrm{w})$ initial 
brine concentration, for a brine/muscle ratio 5 , an effective diffusivity value of $5.9 \times 10^{-10}$ $\mathrm{m}^{2} / \mathrm{s}$ for $\mathrm{NaCl}$ was reported.

Gou et al. (2003) reported the effective moisture diffusivity values for ham pieces brined for 10 days at different $\mathrm{NaCl}$ concentrations and temperatures combinations. Among the treatments, the diffusion was the highest when the meat samples was submerged in $5 \% \mathrm{NaCl}$ solution at $26^{\circ} \mathrm{C}\left(\mathrm{D}_{\mathrm{e}}=7.4 \times 10^{-11} \mathrm{~m}^{2} / \mathrm{s}\right)$. Wang et al. (2000) developed a model for predicting the salt concentration in different points of a salmon filet at different rigor states at room temperature and atmospheric pressure. The values ranged from $0.9-1.5 \times 10^{-10} \mathrm{~m}^{2} / \mathrm{s}$. The diffusion coefficient of nitrite in calf meat was $1.1 \times 10^{-10} \mathrm{~m}^{2} / \mathrm{s}$ (Oztan, et al., 2005). These values were enhanced by the presence of sodium chloride in the diffusing solution (Pinotti, Graiver, Califano, Zaritzky, 2002). The diffusion coefficient of sodium tripolyphosphate solution, which was an additive with antioxidative, antimicrobial and color development properties, was equal to $1.8 \times 10^{-9}$ $\mathrm{m}^{2} / \mathrm{s}$ (Unal et al., 2004). NaCl diffusion coefficient values were reported by Sabadini et al. (1988) who obtained a value of $1.94 \times 10^{-9} \mathrm{~m}^{2} / \mathrm{s}$ when salt drying beef. Del Valle and Nickerlson (1967) reported 1.18 to $1.4510^{-9} \mathrm{~m}^{2} / \mathrm{s}$ as the values for $\mathrm{NaCl}$ diffusion coefficients.

Xiong and Kupski (1999) reported an innovative method to evaluate the diffusion of phosphate in chicken filets by the utilization of dyes; however this method did not quantify the amount of solvent infused in the product. Wang et al. (2000) noticed the importance of the fat muscle content on the diffusivity value: a high fat content slowed down the salt diffusion process. As seen mass transfer of different compounds in meats have been investigated under atmospheric conditions, however scarce information 


\begin{tabular}{|c|c|c|c|c|c|c|c|c|c|}
\hline 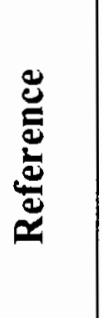 & 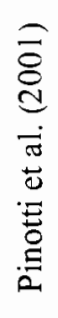 & 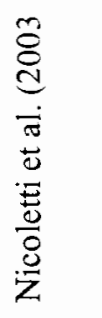 & 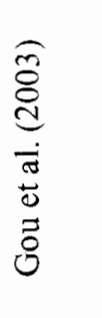 & 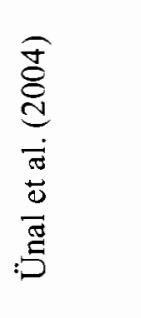 & 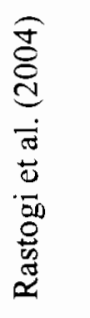 & 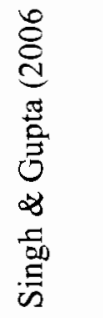 & 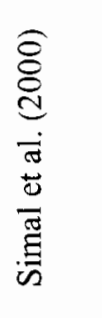 & 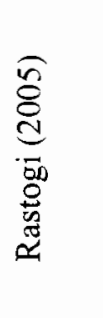 & 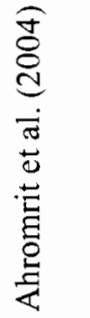 \\
\hline ن & $\begin{array}{l}0 \\
\stackrel{\sim}{\sim}\end{array}$ & 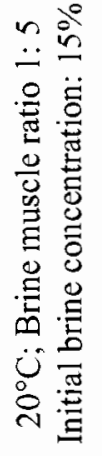 & 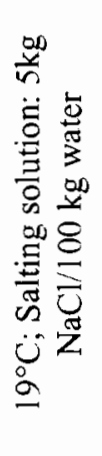 & $\begin{array}{l}n \\
0 \\
0 \\
+ \\
\dddot{3} \\
3 \\
0 \\
0 \\
0 \\
0 \\
0 \\
\vdots \\
0 \\
0 \\
0 \\
0\end{array}$ & $\begin{array}{l}\infty \\
0 \\
0 \\
+ \\
\ddot{\Xi} \\
\stackrel{9}{\Xi} \\
0 \\
0 \\
\ddot{0} \\
0 \\
0 \\
0\end{array}$ & 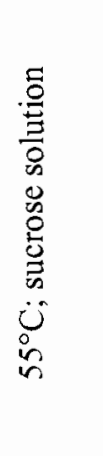 & 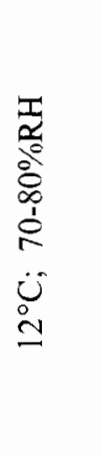 & 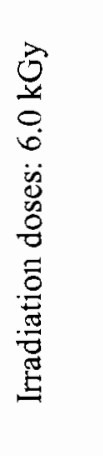 & 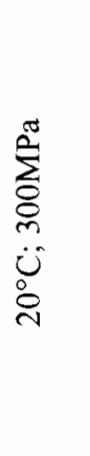 \\
\hline 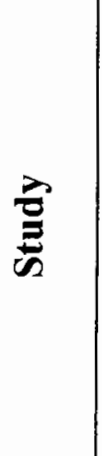 & 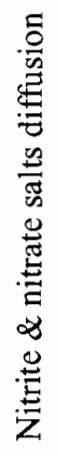 & 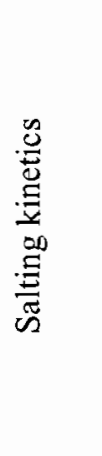 & 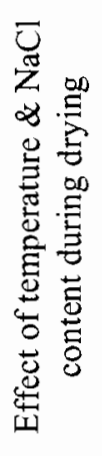 & 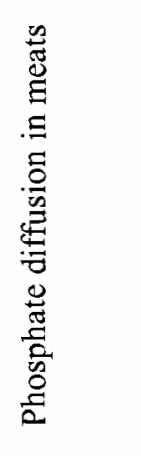 & 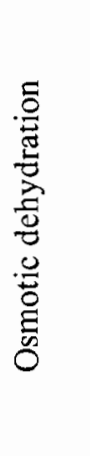 & 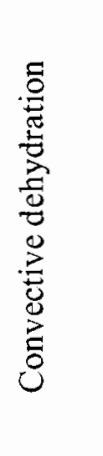 & 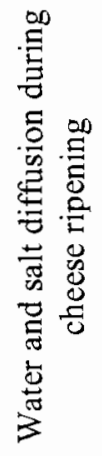 & 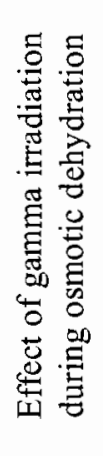 & 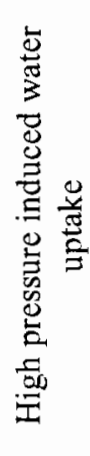 \\
\hline 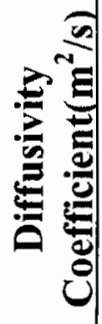 & 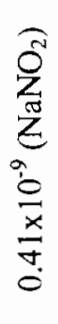 & 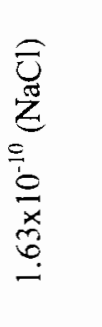 & 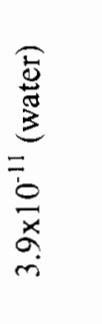 & 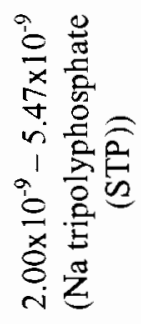 & 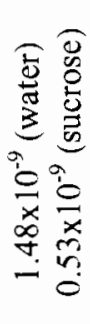 & 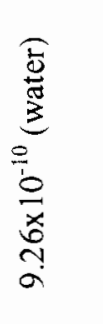 & 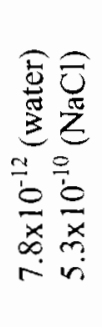 & 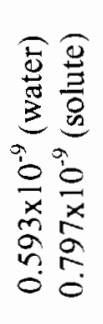 & 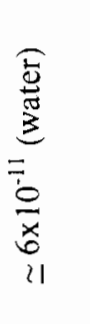 \\
\hline$\stackrel{+}{\stackrel{0}{2}}$ & 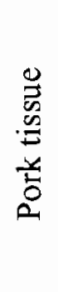 & 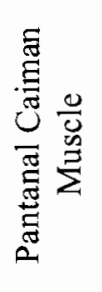 & 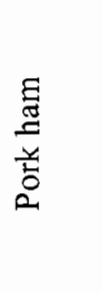 & $\begin{array}{l}4 \\
\dot{D} \\
\infty\end{array}$ & $\begin{array}{l}0 \\
0 \\
0 \\
0 \\
0 \\
0 \\
0 \\
0 \\
0 \\
0 \\
0\end{array}$ & 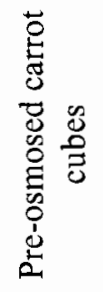 & 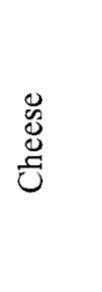 & $\underset{\vec{E}}{\vec{G}}$ & 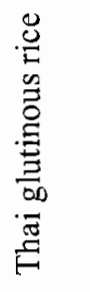 \\
\hline
\end{tabular}

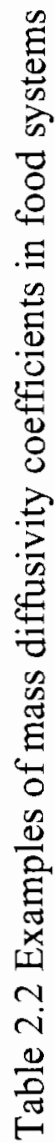


is available on how the application of high pressures would affect the mass transfer of compounds in meats.

\subsubsection{Mass transfer during advanced thermal and nonthermal processes}

Several studies have been conducted to examine the role of mass transfer phenomena during application of novel food processing technologies. Wang and Sastry (1993) examined the effect of ohmic heating in the salt diffusion on potatoes. Rastogi, Esthiagi, \& Knorr (1999) concluded that the application of high electrical pulse enhanced the mass transfer during the osmotic dehydration of carrots. Deumier, Trystram, Collignam, Guedider, and Bohuon (2003) observed that pulse vacuum treatment improved the mass transfer diffusion in poultry meat because through vacuum the air placed in meat tissue spaces is eliminated and are those spaces which are occupied by the infiltrated solution. The effect of high pressure processing on the diffusion phenomena in fruits (Rastogi \& Niranjan, 1998) and vegetables (Sopanangkul, Ledward, \& Niranjan, 2002; Ramaswamy, Balasubramaniam, \& Sastry, 2005, Ahromrit, et al., 2006) were studied. Rastogi et al. (1998) evaluated the influence of high pressure processing as a pretreatment of a posterior osmotic dehydration process on pineapple pieces. Generally, osmotic dehydration is a slow process. A number of techniques have also been employed to improve mass transfer rate during osmotic dehydration. Application of high pressure caused permeabilization of the cell structure. This phenomenon has been exploited to enhance mass transfer rates during osmotic dehydration of pineapple. Authors concluded that the application of high pressure as a pretreatment improved the mass transfer of sucrose in the pineapples. Up to $400 \mathrm{MPa}$, the mass diffusivity increased with pressure, 
while beyond $400 \mathrm{MPa}$ no significant increase was observed. The pressure applied incremented the cell disintegration index in the internal tissue layers, which facilitated the interchange of components.

Ramaswamy et al. (2005) reported the synergistic effect of pressure pretreatment and the hydration temperature on the water uptake behavior of navy beans. Although, the rates of hydration at atmospheric pressure after the high pressure pre-treatment were lower than those hydrations made completely at atmospheric pressure, pressure treated samples achieved final moisture within a shorter time.

Sopanangkul et al. (2002) investigated the mass transfer of sucrose that occurs in potato cylinders under pressure. These researchers concluded that pressurizing up to 400 MPa modified the tissue structure and enhanced diffusivity. Further pressure increases caused starch gelatinization which slowed sucrose diffusion. A similar study by Ahromrit et al. (2006) was done in rice using water as the diffusing agent. Ahromrit et al. (2006) stated that diffusivity was affected by both pressure and temperature. Between $20^{\circ} \mathrm{C}$ and $50^{\circ} \mathrm{C}$, pressure produced an increase in the diffusion up to $200 \mathrm{MPa}$. In the same temperature range, higher pressures caused a lower diffusion. Further, a temperature higher than $60^{\circ} \mathrm{C}$ produced a decrease in diffusivity coefficient values. Starch gelatinization during elevated pressure-temperature combination might have reduced the diffusivity values.

\subsection{Effect of Sodium Chloride on Meat}

Sodium Chloride has been widely used in meat products due to its favorable effects on the meat quality including shelf-life extension, flavor enhancement and protein 
solubilization. Product preservation is achieved by lowering the water activity and increasing the ionic strength; therefore less water is available for microbial activity. The ability of $\mathrm{NaCl}$ to solubilize proteins is essential to extract salt-soluble proteins such as myofibrillar proteins (myosin and actin) and sarcoplamic proteins producing an increase in the muscle tenderness. Besides, the liberation of myofibrillar proteins helps in fat particle emulsification (Barbout, 2002; Smith, 2001; Aktas, Aksu, \& Kaya, 2003).

Salting-in is a process where meat pieces are immersed in moderate to low concentration salt solutions so that meat gains more water (Fig. 2.5). The amount of water gained depends on factors such as $\mathrm{pH}$, temperature, rigor status, salt solution concentration, presence of other additives, massaging, tumbling etc. Maximum water uptake is observed when the salt concentration is around the physiological ionic strength, approximately 0.8 to $1 \mathrm{M}$ (Offer \& Trinick, 1983). At this concentration the proteins assemblies inside the myofibrils get dissociated. This results in a lateral expansion of the myofibrils creating more space inside the myofibrils to hold more water (Offer \& Knight, 1988). Further $\mathrm{NaCl}$ addition diminished the muscle water holding capacity progressively. Thus, the muscle swelling decreases and shrinkage of the myofibrils is present when concentration is more than $4 \mathrm{M}$ (Offer et al., 1988). This phenomenon is known as salting-out (Fig. 2.6).

\subsection{Effect of High Pressure Processing on Meats}

Together with the inactivation of microorganisms, pressurization on meat produces alterations of its structure, color and texture. Those changes were possibly due to modification in enzymes, proteins and lipids (Rastogi, Raghavarao, Balasubramaniam, 
Niranjan \& Knorr, 2006; Cheftel \& Culioli, 1997). The type and extension of those modifications depended on the target pressure, process temperature and pressure hold time (Ma \& Ledward, 2004; Cheftel et al., 1997).

\subsection{Pressure effect on the Myofibrillar proteins}

The effect of the pressure on the myofibrilar structure of the meat has been extensively studied. High pressure processing modified the myofibril structure which in turn affected the myofibril functional properties. Those alterations were function of the target pressure, temperature and holding time (Jimenez Colmenero, 2002). High pressure processing produced the fragmentation of the myofibrils, reduced interactions between the connection and myosin filaments, and altered the endomysium structure (Kamiyama, Ikeuchi, Suzuki, Kim, Hayashi, \& Ito, 2001). Since higher myofibrillar expansion should occur to produce higher water retention (Offer et al., 1988), pressure may be contributing to this by facilitating the interactions between protein and water.

One of the principal effects of the application of relatively low pressures $(<300$ $\mathrm{MPa}$ ) to meat was the increase in the solubilisation of the myofibrillar proteins (Cheftel et al., 1997; Macfarlane, 1974; Macfarlane \& McKenzie, 1976). Macfarlane (1974) reported that pressurization of $150 \mathrm{MPa}$ produced a higher solubility of ovine myofibrillar proteins in contact with a $0.5 \mathrm{M} \mathrm{NaCl}$ solution. This effect was dependent factors such as $\mathrm{pH}$, temperature, salt type, concentration (Macfarlane et al., 1976). Similar results were found for rabbit skeletal myofibrils in which the pressure up to $300 \mathrm{MPa}$ and the solubilisation of myofibrillar proteins have a sigmoidal relationship. The principal proteins solubilised those present in the thin filaments and M-protein (Suzuki, Suzuki, \& Saito, 1991). 


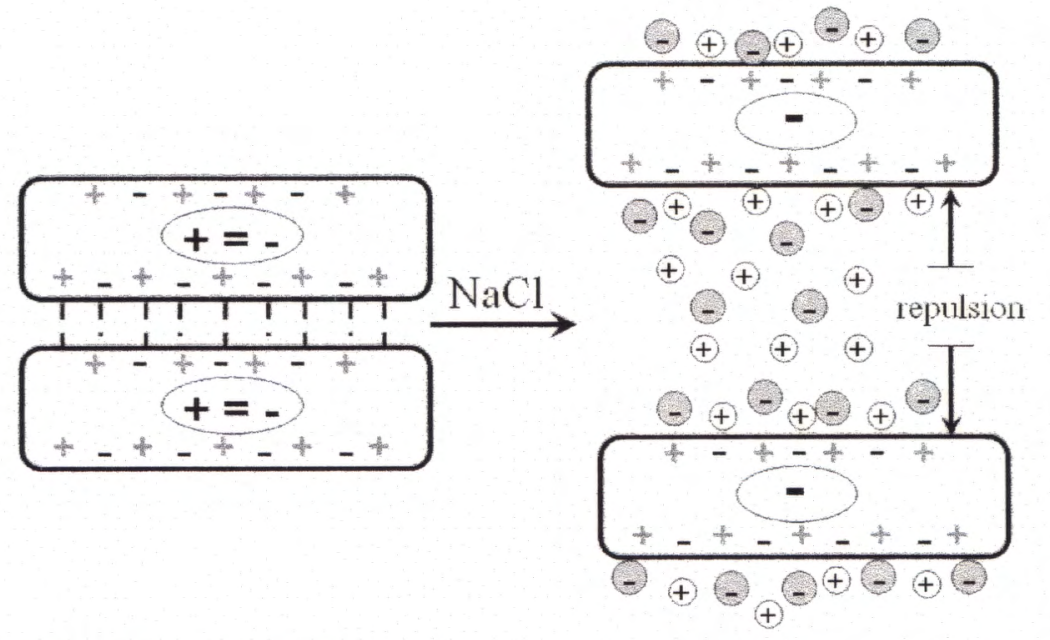

Figure 2.5. Salting-in in meat

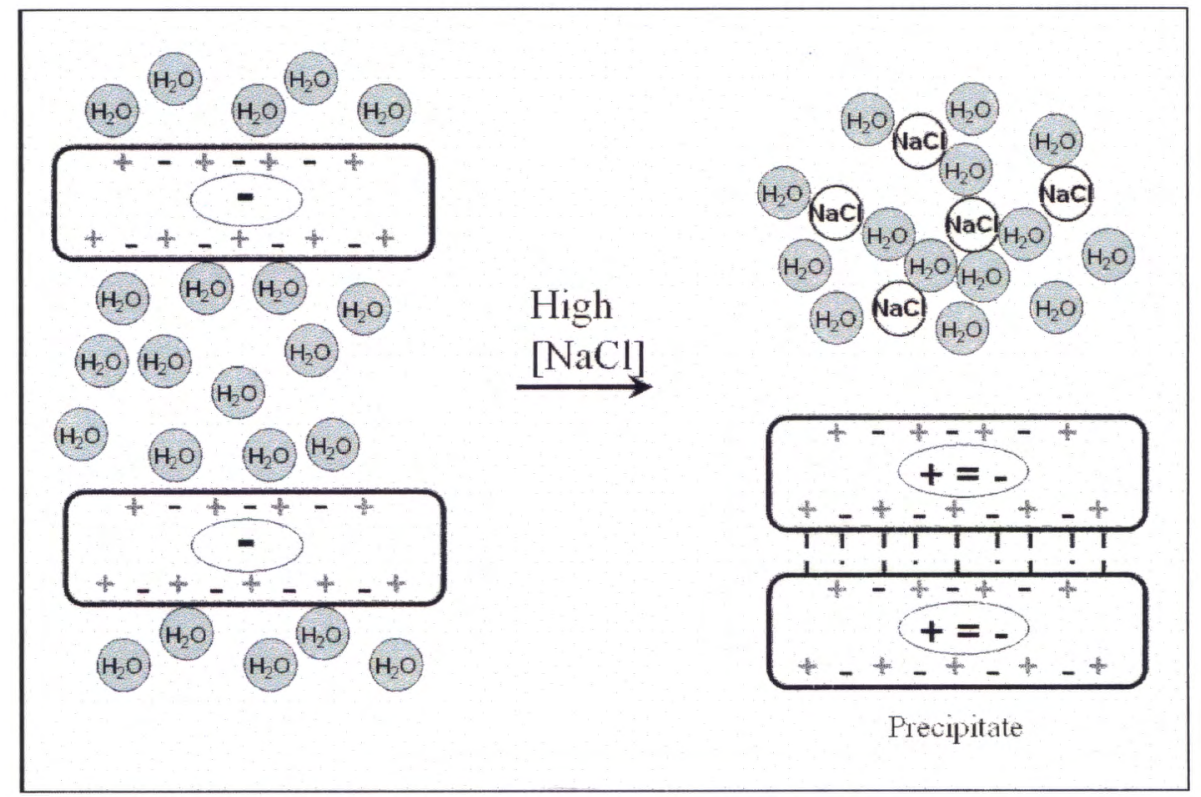

Figure 2.6. Salting-out in meat 
According to Suzuki et al. (1991) the increase of the salt concentration from $0.1 \mathrm{M}$ to $1.0 \mathrm{M}$ produced an appreciable increment in the percentage of solubilised proteins. With higher protein solubility capacity higher water - protein interaction was expected (Cheftel et al., 1997). Further increase in pressure levels caused a decrease in the solubility of the proteins present in the meat tissue (Cheftel et al., 1997; Goutefongea et al., cited by Cheftel et al., 1997). Angsupanich, Edde, \& Ledward (1999) found that $300 \mathrm{MPa}$ pressure treatment at room temperature, for $20 \mathrm{~min}$ caused denaturation of myosin in turkey breast and suggested that the myofibrillar proteins were stabilized by hydrogen bonds forming new structures. Some adverse effect on the meat products have been observed when pressures $>150 \mathrm{MPa}$. Meat batters processed at $>200 \mathrm{MPa}$ for 5 minutes had a lower cooking yield and toughened texture (Mandava, Fernandez, Juillerat, 1994). Authors thought denaturation of proteins as one possible reason.

The combination of pressure and heat produced the disruption of thick and thin filaments in the muscle. A non-reversible disaggregation of the myosin of thick filaments was one of the principal effects of the application of pressure and heat. Application of $100 \mathrm{MPa}-60^{\circ} \mathrm{C}$ treatment made irreversible effect on the myofibrillar structure however the connective tissue was not influenced (Bouton, Ford, Harris, Macfarlane, \& O'Shea, 1977; Ma et al., 2004).

The application of pressure on chicken and pork batters with added sodium chloride showed to produce a high water and fat binding capacity. Water loss was reduced by through the formation of less rigid gels but with better binding properties. The synergetic effect of salt and pressure was more appreciable when the processing 
temperature was 70 to $80^{\circ} \mathrm{C}$ (Jimenez-Colmenero, Fernandez, Carballo \& FernandezMartin, 1998).

With the exception of the earlier investigations made by Macfarlane $(1974,1976)$ on extracted proteins, the combined effect of salt and pressure have not been investigated in animal tissue. More information about this area would allow a better understanding about the different changes observed on meats under pressure.

\subsection{Pressure effect on meat texture}

Texture is a commonly investigated property on meat as affected by the pressure. Meat texture depended on both the myofibrillar structure and the connective tissue network (Bouton et al., 1977; Harris \& Shorthose, 1988; Macfarlane, 1973). Combined $103 \mathrm{MPa}-35^{\circ} \mathrm{C}$ treatment for 2 minutes in different beef and sheep muscles decreased in the Warner-Bratzler (W-B) shear force values and reduced cooking loss (Macfarlane, 1973). Macfarlane, Turner and Ratcliff (1976) also reported similar results for beef biceps femoris muscles subjected to $103 \mathrm{MPa}$ treatment for 6 minutes. The authors suggested that the reduction was due to a higher myofibrillar disruption, however the muscle membrane was believed not damaged by the pressure treatment since a lower fluid loss was observed in pressure treated samples. The disintegration of the M-line can be related with changes in the texture of the meat (Macfarlane et al., 1976). The breakages at the $\mathrm{Z}$ line were related with the increase of tenderness of meat (Suzuki, Watanabe, Iwamura, Ikeuchi, \& Saito, 1990).

The application of pressure $<150 \mathrm{MPa}$ had different results. According to Cheftel et al. (1997), treatments less than $150 \mathrm{MPa}$ at near atmospheric temperature $\left(<30^{\circ} \mathrm{C}\right)$ 
caused changes in the meat but did not alter the tenderness. Macfarlane et al. (1980) observed that texture after pressurization depends on the length of the sarcomeres. With shorter sarcomeres, the shear values increased due to pressurization, while long sarcomeres in the muscle resulted in higher tenderness. Macfarlane et al., 1978, reported that the sarcomere ultrastructure of stretched bovine m. semimembranosus was seriously affected by the application of $150 \mathrm{MPa}$ pressure treatment at $30^{\circ} \mathrm{C}$. Pressure level was enough to diminish the amount of myosin and induced connectin breakdown with the formation of low thermal resistant components.

Application of pressures greater than $150 \mathrm{MPa}$ had a marked effect on different meat components including tenderness (Cheftel at el., 1997). Application of $200 \mathrm{MPa}$ caused lower hardness in beef muscle when processed at 60 to $70^{\circ} \mathrm{C}$ (Ma et al., 2004). When a similar study was made in chicken, Zamri, Ledward, and Frazier (2006) reported that up to $50^{\circ} \mathrm{C}$ both heat and pressure synergistically affect the hardness of the muscle. At higher temperatures $\left(60-70^{\circ} \mathrm{C}\right)$ the trend was unclear. The authors stated that the increasing hardness could be induced by the unfolding of myosin and actin, the formation of new structures and the compression of the thick filaments of the myofibrils. Suzuki, Homma, Kim, Ikeuchi, Sugiyama, and Saito (2001) reported that the conversion of $\alpha$ connectin to $\beta$-connectin was almost complete at $300 \mathrm{MPa}$. Similar results were found by Kim, Ikeuchi, \& Suzuki (1992) in pre-rigor rabbit m. longissimus dorsi, who also reported that nebulin was completely denatured at $200 \mathrm{MPa}$.

\subsection{Pressure effect on the meat ultrastructure}


The observation of the ultrastructure of the muscle gives an idea of how the effect of pressure was on the different section of the muscle. Besides, these alterations were related with other properties such as texture, water holding capacity and others. Suzuki et al., (1990) reported that high pressure processed bovine muscle presented no significant changes in its ultrastructure when treated up to $150 \mathrm{MPa}$ for 5 minutes at $20^{\circ} \mathrm{C}$. However, elevated pressures ( $>200 \mathrm{MPa}$ ) produced disappearance of the M-band. Similar results were reported by Macfarlane et al. (1978) who stated that this was the principal effect of the application of $100 \mathrm{MPa}$ for $60 \mathrm{~min}$ at $25^{\circ} \mathrm{C}$ to ovine muscle. Similarly change in A band structure was reported, when subjected to pressures $\geq 200 \mathrm{MPa}$ (Suzuki et al. 1990). This resulted in formation of longitudinal fissures. Suzuki et al. $(1990 ; 1991)$ studied effect of pressure on beef and rabbit skeletal muscles. Application of $200 \mathrm{MPa}$ resulted in near loss of continue sarcomere structure, breakages of A and I filaments, loss of M-line and thickening of Z-line. An application of $300 \mathrm{MPa}$ produced a segmentation of the Aband. Breakage of the Z-line in the samples treated at $300 \mathrm{MPa}$ was reported. The observations were consistent with those made by Macfarlane et al. (1978) in ovine muscle tissue. This rupture could be due to both the effect of the pressure and the salt. Macfarlane et al. (1978) suggested that the actin present in the Z-line may be altered by the application of pressure. On the other hand, the presence of salt produced a fragmentation of the Z-line (Offer et al., 1988). A lack of information which explains changes in the ultrastructure caused by the pressurization and salt diffusion is observed. 


\section{CHAPTER 3}

\section{EFFECT OF HIGH PRESSURE ON MOISTURE AND NaCI DIFFUSION INTO TURKEY BREAST}

\subsection{ABSTRACT}

High pressure processing (HPP) affects food component diffusion. This study evaluated the effect of pressure (0.1-300 MPa) on the diffusion of $\mathrm{NaCl}$ and water into turkey breast meat processed at $25^{\circ} \mathrm{C}$. $\mathrm{NaCl}$ and water diffusion were found to be a function of pressure and holding time. During the pressure come-up-time diffusion of water and $\mathrm{NaCl}$ into the sample was enhanced as compared to control. The diffusion coefficient of moisture infusing out of the sample was found to be a minimum at 150 $\mathrm{MPa}$. The diffusion coefficient of $\mathrm{NaCl}$ infusing into the sample was a maximum value at $150 \mathrm{MPa}$. Hardness, gumminess and chewiness of sample increased with holding time and were minimal at $150 \mathrm{MPa}$. Ultrastructure images revealed that $150 \mathrm{MPa}$ treatments caused swelling of myofibrils, disappearance of the M-line, reduced difference in the density of the A-band and I-band and breaking of segments of Z-line. HPP could be a useful technique for the salting of turkey meat.

Keywords: High pressure processing, Mass transfer, turkey breast, salting, ultrastructure, texture 


\subsection{INTRODUCTION}

Salting of meat has long worldwide traditions as a preliminary operation in smoking, drying and cooking processes. This aids in enhancing product texture, flavor and shelf life (Smith, 2001; Graiver, Pinotti, Califano \& Zaritzky, 2006). During salting process, two main simultaneous flows, $\mathrm{NaCl}$ and water movement, occur and the properties of muscle vary due to changes in the water and $\mathrm{NaCl}$ content. Diffusion of salt and water in meat takes place due to the differences in concentration and osmotic pressures between muscle cells and the salting agent.

When meat cuts are immersed in curing salts, salt penetration is related to the equilibrium between the interior salt concentration of the meat and the external brine solution. Diffusion of salt in meat has been widely studied (Djelveh \& Gros, 1988; Dussap \& Gros, 1980; Fox, 1980; Gros, Dussap \& González-Méndez, 1984; Sabadini, Carvalho, Sobral \& Hubinger, 1998; Wang, Tang \& Correia, 2000; Wood, 1966). Application of high pressure has been reported to accelerate the diffusion of components into the food. Pressure causes structural transformations in the food which may alter the diffusion coefficients. Rastogi and Niranjan (1998) have demonstrated that the application of pressure pretreatment resulted in increased rate of water and solute diffusion during osmotic dehydration of pineapples. Sopanangkul, Ledward, and Niranjan (2002) showed an increase in the diffusion of sucrose in potato cylinders up to $400 \mathrm{MPa}$, beyond which it decreased due to starch gelatinization. Ahromrit, Ledward and Niranjan (2004) studied the effect of high pressures on glutinous rice (or sticky rice) up to 600 MPa. Authors reported that the overall rates of water uptake and the equilibrium moisture content increased with pressure and temperature during soaking. Pressures below 300 
$\mathrm{MPa}$ and temperatures below $60^{\circ} \mathrm{C}$ yielded higher effective diffusion coefficients. Above $300 \mathrm{MPa}$, the effective diffusion coefficient was not significantly dependent on temperature, which was attributed to starch gelatinization.

Application of high pressure processing (HPP) is being investigated in meat processing for microbial inactivation, meat tenderization, gelation or lipid oxidation (Lamballerie-Anton, Taylor \& Culioli, 2002). Understanding transport mechanisms during HPP will facilitate the development of novel pressure applications and process optimization. However, to the best of our knowledge, no information is available in literature regarding the mass transfer behavior of meat under high pressures. The main objectives of this study are to a) determine the effect of high pressure processing on the $\mathrm{NaCl}$ and water diffusion in turkey breasts meat, b) estimate the corresponding diffusion coefficients and c) study the meat textural changes due to pressure treatment.

\subsection{MATERIALS AND METHODS}

\subsubsection{Sample preparation}

Turkey breasts from 140-days-old Commercial Tom Turkeys were procured in frozen conditions from a local poultry processor (Cooper Farms, Oakwood, OH). After slaughtering, the muscles were placed in the freezer and temperature of the breast reached $-58^{\circ} \mathrm{C}$ within 72 hours, transported in frozen condition to the laboratory and maintained at $-40^{\circ} \mathrm{C}$. Before the experiment, the frozen turkey breasts were transferred at $-10^{\circ} \mathrm{C}$ for 48 hours and then thawed at $4^{\circ} \mathrm{C}$ for 18 hours (Deumier, Trystam, Collignam, Guedider, \& Bohuon, 2003). The turkey breasts were sliced using a meat slicer (model No. 1612, Hobart Slicer, Troy, OH, USA) and then cut in to cubes $(20 \times 20 \times 20 \mathrm{~mm})$. Samples 
were equilibrated to $25^{\circ} \mathrm{C}$ for 15 minutes before processing. The $\mathrm{pH}$ of the sample was

5.85. The samples were immersed in $50 \mathrm{~g} / \mathrm{L} \mathrm{NaCl}$ solution and vacuum packaged in high barrier bags consisting of Nylon/EVOH/ polyethylene (Winpak Ltd, Canada). The sample to solution ratio was maintained at 1:6. Turkey breast suspended in $50 \mathrm{~g} / \mathrm{L} \mathrm{NaCl}$ solution held at $25^{\circ} \mathrm{C}$ served as the control sample.

\subsubsection{High pressure processing}

High pressure processing of turkey breast was carried out using a Quintus Food Processor (QFP-6, Flow Autoclave Systems, Columbus, OH). The pressure transmitting fluid was a 1:1 mixture of distilled water and food grade propylene glycol (Houghto-Safe 620-TY, Houghton International Inc., Valley Forge, PA). The rate of pressurization was approximately $258 \mathrm{MPa} / \mathrm{min}$. The samples were processed at various pressures (50 to 300 MPa) for $1,2,3,5,10$ and 15 minutes at $25^{\circ} \mathrm{C} \pm 1{ }^{\circ} \mathrm{C}$. Similarly, pressure-come-up time effects were documented by processing the samples at various target pressures for $0.1 \mathrm{~s}$. To achieve a temperature of $25^{\circ} \mathrm{C}$ during the pressure holding time, the initial temperature of the sample before HPP were lowered to compensate the rise in temperature because of compression heating during high pressure treatments (Ting, Balasubramaniam \& Raghubeer, 2002). After processing, the pouch was cut open, samples were rinsed in distilled water, dried with a tissue paper to remove any residual water adhered to the surface, and subsequently packed in a plastic freezer bag, immediately air blast frozen at $-20^{\circ} \mathrm{C}$, and stored in the freezer at $-20^{\circ} \mathrm{C}$ until analysis. The final $\mathrm{pH}$ of the samples treated under atmospheric pressure, $150 \mathrm{MPa}$ and $300 \mathrm{MPa}$ were $5.72,5.68$ and 5.79 , respectively. 


\subsubsection{Moisture and $\mathrm{NaCl}$ determination}

The moisture content of turkey breast pieces was determined using a Lab Wave 9000 moisture/solids analyzer (CEM Corp. Matthews, NC) following the AOAC 2000, Method No. 39.1.03. The values were expressed in $\mathrm{kg}$ of water/ $\mathrm{kg}$ of initial dry solids. $\mathrm{NaCl}$ content was determined by the modified Vohlrad method (AOAC 2000, Method No. 935.47). The $\mathrm{NaCl}$ concentration of each piece was expressed as $\mathrm{kg}$ of $\mathrm{NaCl} / \mathrm{kg}$ of initial dry solids. The experiments were carried out in triplicate and average values were reported.

\subsubsection{Texture profile analysis}

INSTRON 5542 (Instron Inc. Canton, MA) with a $500 \mathrm{~kg}$ load cell was used to conduct texture profile analysis (TPA) of pressure treated and control turkey breast samples. The cubical sample $(20 \mathrm{~mm} \times 20 \mathrm{~mm} \times 20 \mathrm{~mm})$ were compressed $(80 \%$ compression) on a non-lubricated platform using a flat disc probe (dia $38 \mathrm{~mm}$ ), with a constant cross-head speed of $2 \mathrm{~mm} / \mathrm{s}$ (Angsupanich \& Ledward, 1998). Texture was measured perpendicular to the muscle fiber orientation. The peak force required to compress the samples were referred as a measure of hardness (Bourne, 1978). The cohesiveness, springiness, gumminess and chewiness were determined from TPA following the definition as described by Bourne (1978). Cohesiveness is expressed as the dimensionless quotient of the areas represented by the work to be done for two bites. Springiness (elasticity) is defined as the proportion of compression distance recovered between the first and the second compression. Gumminess is defined as the product of 
hardness and cohesiveness, whereas chewiness is the product of hardness, cohesiveness and springiness. The data were collected for five replicates and average values are reported.

\subsubsection{Statistical analysis}

Statistical analysis was carried out using the SAS (SAS, release 9.2.1, SAS Institute Inc, Cary, NC, USA) software package to analyze the effect of pressure level, holding time on moisture, $\mathrm{NaCl}$ contents and meat textural properties. The general linear model and least significant difference procedures were used to compare means. Mean differences among pressure treatments and holding times were calculated by Duncan's multiple range tests.

\subsubsection{Structure analysis}

The ultrastructure changes in turkey breast muscle due to high pressure were evaluated using transmission electron microscopy (TEM). Six blocks of control and pressure treated tissue, each measuring $4 \times 2 \times 1 \mathrm{~mm}$, were cut from the surface of anterior end turkey muscle and were subjected to a fixative solution consisting of $3 \%$ glutaraldehyde and $4 \%$ paraformaldehyde in $0.1 \mathrm{M}$ phosphate buffer containing $0.1 \mathrm{M}$ sucrose $\left(\mathrm{pH} \mathrm{7.4)}\right.$ for $3 \mathrm{~h}$ at $20^{\circ} \mathrm{C}$. The fixed specimens were washed three times with 0.1 phosphate buffer containing $0.1 \mathrm{M}$ sucrose. The samples were subjected to $1 \% \mathrm{OsO}_{4}$ for 1 hour and then rinsed three times with buffer solution and left overnight at $4^{\circ} \mathrm{C}$. The samples were then dehydrated by immersing them in ascending concentrations of ethanol series $(70 \%, 80 \%, 95 \%$ and $100 \%)$ for about 10 minutes each. This was followed by 
washing for 10 min each consecutively in two changes each of 50:50\% ethanol:propylene oxide (PO) and 100\% PO. Both untreated and pressure treated specimens were then transferred into a vial containing PO: Spurr resin (1:1), and agitated in a rotator (Ted Pella Inc., Reading, CA, USA) for 1 hour. The solution was then replaced with PO: Spurr resin (1:2) and again agitated overnight. Resulting specimens were transferred into $100 \%$ Spurr resin in an embedding dish and held at $60^{\circ} \mathrm{C}$ for $24 \mathrm{~h}$. Ultrathin microtome longitudinal sections $(80 \mathrm{~nm})$ were obtained on a Reichert Ultracut E ultramicrotome and mounted on grids and stained with $2 \%$ aqueous uranyl acetate followed by Reynolds lead citrate (Yoon, 2003; Jin, Zhu \& Xu, 2006). Specimens were examined with FEI Technai Spirit transmission electron microscope (FEI Company, Hillsboro, OR, USA) operated at $80 \mathrm{kV}$. Photomicrographs were made at magnification of $x 23,000$.

\subsubsection{Determination of water and $\mathrm{NaCl}$ diffusivities}

The solution of Fick's second law for diffusion from a rectangular parallelepiped (sides $2 a, 2 b$ and $2 c$ ) result in the following well known equations for the transfer of water and solute, respectively (Crank, 1975; Rastogi et al., 1998; Rastogi, Raghavarao, Niranjan \& Knorr, 2002; Rastogi \& Raghavarao, 2004):

$M_{r}=\frac{\left(m_{t}-m_{\infty}\right)}{\left(m_{0}-m_{\infty}\right)}=\sum_{n=1}^{\infty} C_{n}^{3} \exp \left[-\left(D_{e w}\right)_{p} t_{n}^{2}\left(\frac{1}{a^{2}}+\frac{1}{b^{2}}+\frac{1}{c^{2}}\right)\right]$

and $S_{r}=\frac{\left(s_{1}-s_{\infty}\right)}{\left(s_{0}-s_{\infty}\right)}=\sum_{n=1}^{\infty} C_{n}^{3} \exp \left[-\left(D_{e s}\right)_{P} t_{n}{ }_{n}^{2}\left(\frac{1}{a^{2}}+\frac{1}{b^{2}}+\frac{1}{c^{2}}\right)\right]$ 
where $\mathrm{M}_{\mathrm{r}}$ and $\mathrm{S}_{\mathrm{r}}$ are the moisture and $\mathrm{NaCl}$ ratio; $\mathrm{m}$ and $\mathrm{s}$ represent the moisture and solid content; the subscripts $0, \infty$ and $t$ represent the relevant concentrations initially, at equilibrium, and at any given time; $D_{e w}$ and $D_{e s}$ are the effective diffusivities of water and $\mathrm{NaCl}$, respectively considering cubical configuration; and $\mathrm{C}_{\mathrm{n}}$ is equal to $2 \alpha(1+\alpha) /\left(1+\alpha+\alpha^{2} \mathrm{q}_{\mathrm{n}}{ }^{2}\right)$ where, $\mathrm{q}_{\mathrm{n}}$ 's are the non-zero positive roots of the equation tan $\mathrm{q}_{\mathrm{n}}=-\alpha \mathrm{q}_{\mathrm{n}}$. Here, $\alpha$ is the ratio of volume of solution to that of each piece.

When all the side of parallelepiped are equal $(2 a=2 b=2 c)$, then it reduces to a cubical configuration. Eqs. (1) and (2) reduces to:

$$
M_{r}=\frac{\left(m_{t}-m_{\infty}\right)}{\left(m_{0}-m_{\infty}\right)}=\sum_{n=1}^{\infty} C_{n}^{3} \exp \left[-\left(D_{e w}\right)_{s} \operatorname{tq}_{n}{ }^{2}\left(\frac{3}{a^{2}}\right)\right]
$$

and $\quad S_{r}=\frac{\left(s_{t}-s_{\infty}\right)}{\left(s_{0}-s_{\infty}\right)}=\sum_{n=1}^{\infty} C_{n}^{3} \exp \left[-\left(D_{e s}\right)_{s} t_{n}{ }^{2}\left(\frac{3}{a^{2}}\right)\right]$

For a cubical configuration, Fourier numbers for moisture $\left(\mathrm{F}_{\mathrm{ow}}\right)$ and $\mathrm{NaCl}$ diffusion $\left(F_{o s}\right)$ are defined as $D_{\text {ew }} t .\left(3 / a^{2}\right)$ and $D_{\text {es }} t .\left(3 / a^{2}\right)$, respectively (Rastogi et al., 2004). An approximate form of equations (3) and (4) (for cubical configuration) were graphically represented by plotting $\log \left(\mathrm{M}_{\mathrm{r}}\right.$ or $\left.\mathrm{S}_{\mathrm{r}}\right)$ against the Fourier number (Figure. 1). The slopes of these lines gave $\mathrm{d}\left(\log \mathrm{M}_{\mathrm{r}}\right) / \mathrm{d}\left(\mathrm{F}_{\text {ow }}\right)$ or $\mathrm{d}\left(\log \mathrm{S}_{\mathrm{r}}\right) / \mathrm{d}\left(\mathrm{F}_{\text {os }}\right)$.

The slopes of the experimental lines for moisture and $\mathrm{NaCl}$ diffusion $\left[\mathrm{d}\left(\log \mathrm{M}_{\mathrm{r}}\right) / \mathrm{dt}\right.$ and $\left.\mathrm{d}\left(\log \mathrm{S}_{\mathrm{r}}\right) / \mathrm{dt}\right]$ were obtained by fitting the experimental data to the solution of mass transfer equations for moisture and $\mathrm{NaCl}$ mass transfer during salting process. The rate of change of moisture and $\mathrm{NaCl}$ content were plotted against average moisture and $\mathrm{NaCl}$ 
content, respectively, and the equilibrium moisture and solid contents $\left(\mathrm{m}_{\infty}, \mathrm{s}_{\infty}\right)$ as well as moisture and solid mass transfer coefficients $\left(k_{m}, k_{s}\right)$ were estimated from these plots (Rastogi, Angersbach, Niranjan \& Knorr, 2000).

Considering the equilibrium approach to mass transfer, the following equations for moisture and $\mathrm{NaCl}$ mass transfer can be written (Rastogi et al., 2000):

$$
\begin{aligned}
& -\frac{\mathrm{dm}}{\mathrm{dt}}=\mathrm{k}_{\mathrm{m}}\left(\mathrm{m}-\mathrm{m}_{\infty}\right) \\
& \frac{\mathrm{ds}}{\mathrm{dt}}=\mathrm{k}_{\mathrm{s}}\left(\mathrm{s}-\mathrm{s}_{\infty}\right)
\end{aligned}
$$

where $\mathrm{k}_{\mathrm{m}}$ and $\mathrm{k}_{\mathrm{s}}$ are the moisture and $\mathrm{NaCl}$ mass transfer coefficients. Integration of Eqs. (5) and (6), with the appropriate initial condition, resulted in the following equations:

$$
\begin{aligned}
& \ln \frac{\left(m_{t}-m_{\infty}\right)}{\left(m_{o}-m_{\infty}\right)}=\ln M_{r}=-k_{m} t \\
& \ln \frac{\left(s_{1}-s_{\infty}\right)}{\left(s_{o}-s_{\infty}\right)}=\ln S_{r}=k_{s} t
\end{aligned}
$$

The experimental data $\left(M_{r}\right.$ and $S_{r}$ versus t) were fitted to Eqs. (7) and (8) to yield $k_{m}$ and $k_{s}$, which in turn gave the slopes:

$$
\begin{aligned}
& \frac{\mathrm{d}}{\mathrm{dt}}\left(\log \mathrm{M}_{\mathrm{r}}\right)=-\frac{\mathrm{k}_{\mathrm{m}}}{2.3025} \\
& \frac{\mathrm{d}}{\mathrm{dt}}\left(\log \mathrm{S}_{\mathrm{r}}\right)=\frac{\mathrm{k}_{\mathrm{s}}}{2.3025}
\end{aligned}
$$


$D_{e w}$ and $D_{e s}$ values, considering a cubical configuration, were estimated from the following equations, respectively. (Perry, Green \& Maloney, 1984; Rastogi et al., 2002):

$$
\begin{aligned}
& \mathrm{D}_{\mathrm{ew}}=\left[\frac{\mathrm{d}\left(\log \mathrm{M}_{\mathrm{r}}\right) / \mathrm{dt}}{\mathrm{d}\left(\log \mathrm{M}_{\mathrm{r}}\right) / \mathrm{dF}_{\mathrm{ow}}}\right] \cdot\left(\mathrm{a}^{2} / 3\right) \\
& \mathrm{D}_{\mathrm{es}}=\left[\frac{\mathrm{d}\left(\log \mathrm{S}_{\mathrm{r}}\right) / \mathrm{dt}}{\mathrm{d}\left(\log \mathrm{S}_{\mathrm{r}}\right) / \mathrm{dF}_{\mathrm{os}}}\right] \cdot\left(\mathrm{a}^{2} / 3\right)
\end{aligned}
$$

\subsection{RESULTS AND DISCUSSION}

\subsubsection{Salting of turkey breast at atmospheric pressure}

The change in moisture and $\mathrm{NaCl}$ contents in the meat samples during salting at atmospheric pressure is shown in Figure 3.2. Product moisture and $\mathrm{NaCl}$ content increased with an increase in holding time. The increase in moisture content of meat after immersing in $\mathrm{NaCl}$ solution was due to swelling of the fibers and higher water holding capacity. The observations were similar to those reported by earlier researchers (Offer \& Trinick, 1983; Medyski, Pospiech \& Kniat, 2000; Graiver et al., 2006). The increase in water holding capacity might be attributed to the lateral expansion of myofibrils, which was coupled to protein solubilization. An increase in water binding and hydration in salted meat and muscle fibers were also attributed to enhanced electrostatic repulsion between myofibril filaments causing the filament lattices to expand for water entrapment (Xiong, Lou, Harmon, Wang \& Moody, 2000; Pinotti, Graiver, Califano \& Zaritzky, 2001). Akse, Gundersen, Lauritzen, Ofstad and Solberg (1993) reported that salting-in and swelling of the muscle occurred at lower $\mathrm{NaCl}$ concentration $(<50 \mathrm{~g} / \mathrm{l})$, and no 
salting-out of proteins was observed at this concentration. The values of mass transfer coefficients as well as diffusion coefficients of moisture and $\mathrm{NaCl}$ at atmospheric pressure were obtained and provided along with the equilibrium values in Table 3.1. The values of $\mathrm{NaCl}$ diffusion coefficients are in agreement with the values reported by Sabadini et al. (1988) and Del Valle and Nickerlson (1967) in case of beef and fish salting, respectively. The negative sign of $\mathrm{k}_{\mathrm{m}}$ under atmospheric pressure accounts for the direction of mass transfer that the water is diffusing from salt solution to the turkey breast.

\subsubsection{Salting of turkey breast under high pressure}

The plots for the variation of moisture and $\mathrm{NaCl}$ contents of pressure treated turkey breast sample immediately after the pressure come up time are presented in Figure 3.3. Pressure come-up time during high pressure treatment caused a significant amount of changes in moisture as well as $\mathrm{NaCl}$ content even though the starting material had the same moisture and $\mathrm{NaCl}$ content. Moisture and $\mathrm{NaCl}$ contents during pressure come-up time increased with increasing pressure (up to $150 \mathrm{MPa}$ ) and subsequent increase in pressure to $300 \mathrm{MPa}$ resulted in decreased moisture and $\mathrm{NaCl}$ content $(\mathrm{p}<0.05$, Figure

3.3). This may be attributed to the increase in $\mathrm{NaCl}$ content with pressure treatment up $150 \mathrm{MPa}$ that resulted in increased water holding capacity. The observations were consistent with earlier reports (Offer \& Knight, 1988; Gou, Comaposada \& Arnau, 2003). Authors attributed that an increase in ionic strength due to $\mathrm{NaCl}$ diffusion solubilized the muscle protein, which in turn resulted in higher water holding capacity and tenderness. The pressures above $150 \mathrm{MPa}$ resulted in decrease in solubility of protein, which may be 
due to irreversible denaturation of F-actin in the absence of adenosine triphosphate (ATP) at a pressure around $150 \mathrm{MPa}$ (Macfarlane \& McKenzie, 1976) and complete denaturation was obtained at $300 \mathrm{MPa}$ (Ikkai \& Ooi, 1966). Ikeuchi, Tanji, Kim and Suzuki (1992) reported sulfhydryl content and hydrophobicity of F-actin were maximum at $150 \mathrm{MPa}$ with further increases in pressure, these parameters decreased due to aggregation of actin.

The variation of moisture and $\mathrm{NaCl}$ content with pressure holding time during high pressure processing of turkey breast sample is presented in Figure 3.4a and 3.4b. Within the experimental conditions of the study, increasing pressure holding time increased $\mathrm{NaCl}$ content and decreased moisture content $(\mathrm{p}<0.05)$. The moisture and $\mathrm{NaCl}$ content were always higher than the moisture and $\mathrm{NaCl}$ content of the untreated sample (Figure 3.3, 3.4a and 3.4b). These results were consistent with the observations made by Macfarlane (1974) that the immediate application of pressure resulted in increased high water holding capacity of the protein. Further, as the pressure holding time was increased the water holding capacity decreased due to increase in expressed soluble protein.

The moisture and $\mathrm{NaCl}$ contents for samples subjected to different pressures at the end of pressure-come-up time were different. Therefore, a simple plot of moisture and solid content versus time (Figure $3.4 \mathrm{a}$ and $3.4 \mathrm{~b}$ ) could not be directly used to compare mass transfer characteristics. Hence, the effective diffusivities of moisture (out of the sample), and solute (infusing into the sample) were determined. The relevant values (Table 3.1) indicated that the diffusion coefficient for moisture and $\mathrm{NaCl}$ decreased and increased, respectively up to $150 \mathrm{MPa}$; further increase in pressure to $300 \mathrm{MPa}$ resulted 
in increase in moisture and decrease in $\mathrm{NaCl}$ diffusivity values $(\mathrm{p}<0.05)$. The changes in the cell structure and extent of protein denaturation due to high pressure application may probably be responsible for this observed effect. Thus at a given time, the sample treated at $150 \mathrm{MPa}$ had a higher $\mathrm{NaCl}$ content and consequently gained more moisture than the samples treated at other pressures. The values of diffusion coefficients of moisture as well as $\mathrm{NaCl}$ under high pressure were always higher than the corresponding values at the atmospheric pressure. These observations are in agreement with the results reported by Sopanangkul et al. (2002) and Ahromrit et al. (2006) in case of sucrose diffusion in potatoes and water diffusion in rice, respectively.

\subsubsection{Effect of high pressure treatment on textural properties}

Textural properties of pressure treated turkey breast samples are shown in Figure 3.5. Hardness, gumminess and chewiness of sample decreased with an increase in pressure up to $150 \mathrm{MPa}$, further increase in pressure increased these values up to 300 $\mathrm{MPa}(\mathrm{p}<0.05)$. These results were in agreement with findings of Angsupanich et al. (1998). Authors reported that cod muscle textural properties decreased due to loss of myosin structure at lower pressure (up to $200 \mathrm{MPa}$ ). On the other hand, at higher pressures they were increased because of unfolding of actin and sarcoplasmic protein along with hydrogen bonded networks. On comparing the data in Figure 3.3 and Figure $3.5 \mathrm{a}$, it may be noted that the hardness is linearly related to moisture content (or water holding capacity) of the product (Angsupanich et al., 1998).

Pressure holding time appeared to have influence on hardness, gumminess and chewiness of the meat samples. Cohesiveness and springiness did not change 
significantly during the processing at different pressures $(p<0.05)$. However, the cohesiveness increased with pressure holding time for all pressures.

\subsubsection{Effect of high pressure treatment on ultrastructure}

The ultrastructures of the turkey breast muscles subjected to salting at different pressures and control are compared (Figure 3.6). The control sample had clearly defined M- and Z- lines; and around these lines H- and I- bands, respectively. The A-band was also seen between the two I-bands. The portion between the two Z-lines is called sarcomeres and these subunits are repeated along the length of the myofibril (Figure 3.6a). The salting at atmospheric pressure ( $0.1 \mathrm{MPa}$, Figure $3.6 \mathrm{~b})$ resulted in swelling of myofibrils. The treatment resulted in slight fading of M-and Z- lines. The H-band completely disappeared whereas the length of I-band significantly reduced.

At $150 \mathrm{MPa}$, swelling of myofibrils and disappearance of the M-line were seen. The difference in the density of the A-band and I-band were significantly reduced and broken segments of Z-line was also seen (Figure 3.6c). The length of sarcomere was found to be less in pressurized samples (150 MPa) as compared to control, which may be attributed to pressure-induced contraction (Harris \& Shorthose, 1988; Suzuki, Watanabe, Iwamura, Ikeuchi, \& Saito 1990). Elgasim and Kennick (1982) suggested that the thin filaments pull in towards the center of the A-band to the extend it shaded all the H-band area thus making it indistinguishable from rest of the area, which may be responsible for the reduction of the length of sarcomere. The beginning of the breakage of the Z-line at $150 \mathrm{MPa}$ was probably due to the denaturation of F-actin, which was the principal component of the thin filaments connected to the Z-line (Ikeuchi et al., 1992). However, 
the myofibrils structure was intact, which can hold higher amount of water. These results are in agreement with those of Suzuki et al. (1990) who studied the beef skeletal muscle.

The salting at $300 \mathrm{MPa}$ resulted in significant changes in the structure of myofibrils (Figure 3.6d). The Z-line and I-band were completely destroyed and form a very dense re-aggregation of material around the location of the lost $\mathrm{Z}$ - and $\mathrm{M}$-line. These changes may be responsible for the decrease in water holding capacity at higher pressures $(>150 \mathrm{MPa})$.

\subsection{CONCLUSIONS}

Moderate pressure application (around $150 \mathrm{MPa}$ ) could be a potential technique for the salting of turkey breast meat, with improved textural properties. Pressure treatment of meat up to $150 \mathrm{MPa}$ resulted in approximately 10 -fold increase in $\mathrm{NaCl}$ diffusion coefficient, and thus potentially reduces the salting time in turkey breast sample. The textural properties such as hardness, gumminess and chewiness of sample were found to be minimal at $150 \mathrm{MPa}$. Examination of meat ultrastructure revealed that the myofibrils structure was intact, which led to the increased water holding capacity. The application of high pressure may potentially be used for the infusion of flavors and nutrients in the foods.

\subsection{REFERENCES}

Ahromrit A., Ledward D. A., \& Niranjan, K. (2004). High pressure induced water uptake characteristics of Thai glutinous rice. Journal of Food Engineering, 72(3), 225-233. 
Akse, L., Gundersen, B., Lauritzen, K., Ofstad, R., \& Solberg, T. (1993). Saltfisk: saltmodning, utproving av analysemeetoder, misfarget salfisk. Tromso, Norway: Fiskeriforskning, p 1-61.

Angsupanich, K., \& Ledward, D. A. (1998). High pressure treatment effect on cod (Gadus morhua) muscle. Food Chemistry, 63(1), 39-50.

AOAC (2000). Official Method of Analysis (15 $5^{\text {th }}$ Ed.) Arlington, VA: Association of Official Analytical Chemists Method No. 39.1.03 and 935.47.

Bourne, M. C. (1978). Texture profile analysis. Food Technology, 32 (7), 62-66.

Crank, J. (1975). The mathematics of diffusion. London, Ely House: Oxford University Press.

Del Valle, F.R., \& Nickerlson, J. T. (1967). Studies on salting and drying fish. Dynamic aspect of the salting of fish. Journal of Food Science, 32(1), 218-224.

Deumier, F., Trystam, G., Collignan, A., Guedider, L., \& Bohuon, P. (2003). Pulsed vacuum brining of poultry meat: interpretation of mass transfer mechanisms. Journal of Food Engineering, 58(1), 85-93.

Djelveh, G., \& Gros, J. B. (1988). Measurement of effective diffusitivities of ionic and non-ionic solutes through beef and pork muscles using a diffusion cell. Meat Science, $23(1), 11-20$. 
Dussap, C. G., \& Gros, J. B. (1980). Diffusion-sorption model for the penetration of salt in pork and beef muscle. In P. Linko, Y. Malkii, J. Olkku, \& J. Larinkari (Eds.). Food process engineering (vol. 1, pp. 407). London: Elsevier Applied Science.

Elgasim, E.A., \& Kennick, W.H. (1982). Effect of high hydrostatic pressure on meat microstructure. Food Microstructure, 1(1), 75-82.

Fox, J. B. (1980). Diffusion of chloride, nitrite and nitrate in beef and pork. Journal of Food Science, 45(4), 1740-1744.

Gou, P. Comaposada J., \& Arnau J. (2003) NaCl content and temperature effects on moisture diffusivity in the Gluteus medius muscle of pork ham. Meat Science, 63(1), 2934.

Graiver, N., Pinotti, A., Califano, A., \& Zaritzky, N. (2006). Diffusion of sodium chloride in pork tissue. Journal of Food Engineering, 77(4), 910-918.

Gros, J. B., Dussap, C. G., \& González-Méndez, N. (1984). Engineering Sciences in the Food Industry. In B. M. McKenna, Engineering and food (Vol. 1) (pp.287-322). London: Elsevier Applied Science.

Harris P. V., \& Shorthose, W. R. (1988). Meat Texture. In R. Lawrie, Developments in meat science (Vol. 4) (pp.245-296). London: Elsevier Science Publishers. .

Ikeuchi, Y., Tanji, H, Kim, K., \& Suzuki, A. (1992). Mechanism of heat-induced gelation of pressurized actomyosin: pressure-induced changes in actin and myosin in actomyosin. Journal of Agricultural and Food Chemistry, 40, 1756-1761. 
Ikkai, T., \& Ooi, T. (1966). The effects of pressure on F-G transformation of actin. Biochemistry, 5(5) 1551-1560.

Jin, T. X., Zhu H. M., \& Xu, L. (2006). Moisture movement characteristics and their effect on the ultrastructure of cooked meat during vacuum cooling, Biosystems Engineering, 95(1), 111-118.

Lamballerie-Anton, M. de, Taylor, N. R., \& Culioli, J. (2002). High pressure processing of meat, In Meat Processing: Improving Quality (Eds) D. B. Macdougall, Joseph Kerry, David Ledward, CRC Press, 313-324.

Macfarlane, J. J. (1974) Pressure induced solubilization of meat proteins in saline solution. Journal of Food Science, 39, 542-547.

Macfarlane, J. J., \& McKenzie, I.J. (1976) Pressure induced solubilization of myofibrillar proteins. Journal of Food Science, 41, 1442-1446.

Medyski, A., Pospiech, E., \& Kniat, R. (2000) Effect of various concentrations of lactic acid and sodium chloride on selected physico-chemical meat traits. Meat Science, 55(3), 285-290.

Offer, G., \& Knight, P. (1988). The structural basis of water holding in meat. Part 1: General principles and water uptake in meat processing. In R. Lawrie, Developments in meat science (Vol. 4) (pp. 63-171). London: Elsevier Science Publishers.

Offer, G., \& Trinick, J. (1983). On the mechanism of water holding in meat: the swelling and shrinking of myofibrils. Meat Science, 8(4), 245-281. 
Perry, R. H., Green, D. W., \& Maloney, J. O. (1984). Perry's Chemical Engineer's Handbook, $6^{\text {th }}$ ed., New York, McGraw Hills. 20.11-20.14.

Pinotti, A., Graiver, N., Califano, A., \& Zaritzky, N. (2001). Diffusion of nitrite and nitrate salts in pork tissue in the presence of sodium chloride. Journal of Food Science, $67(6), 2165-2171$.

Rastogi. N. K., Angersbach, A., Niranjan, K., \& Knorr, D. (2000). Rehydration kinetics of high-pressure pretreated and osmotically dehydrated pineapple. Journal of Food Science, 65(5), 838-841.

Rastogi, N. K., \& Niranjan, K. (1998). Enhanced mass transfer during osmotic dehydration of high pressure treated pineapple. Journal of Food Science, 63(3), 508-511.

Rastogi N. K., \& Raghavaro, K. S. M. S. (2004). Mass transfer during osmotic dehydration of pineapple: considering Fickian diffusion in cubical configuration. Lebensmittel-Wissenschaft und-Technologie, 37(1), 43-47.

Rastogi, N. K., Raghavarao, K. S. M. S., Niranjan, K., \& Knorr, D. (2002). Recent Developments in osmotic dehydration: Methods to enhance mass transfer. Trends in Food Science and Technology. 13(2), 58-69.

Sabadini, E., Carvalho, B. C., Jr., Sobral, P. J. do A., \& Hubinger, M. D. (1998). Mass transfer and diffusion coefficient determination in the wet and dry salting of meat. Drying Technology, 16(10), 2095-2115. 
Smith, D. (2001). Functional properties of muscle proteins in processed poultry products. In A. Sams, Poultry meat processing. (pp.181-194). Boca Raton, FL: CRC Press.

Sopanangkul, A., Ledward, D. A., \& Niranjan, K. (2002). Mass transfer during sucrose infusion into potatoes under high pressure. Journal of Food Science, 67(6), 2217-2220.

Suzuki A., Watanabe, M., Iwamura K., Ikeuchi Y., \& Saito M. (1990). Effect of high pressure treatment on the ultra-structure and myofibrillar protein of beef skeletal muscle. Agricultural and Biological Chemistry, 54(12), 3085-3091.

Ting, E., Balasubramaniam, V. M., \& Raghubeer, E. (2002). Determining thermal effects in high-pressure processing. Food Technology, 56(2), 31-35.

Wang, D., Tang, J., \& Correia, L. (2000). Salt diffusivities and salt diffusion in farmed Atlantic salmon muscle as influenced by rigor mortis. Journal of Food Engineering, 43(2), 115-123.

Wood, F. W. (1966). The diffusion of salt in pork muscle and fat tissue. Journal of Science and Food Agriculture, 17(1), 138-140.

Xiong, Y., Lou, X., Harmon, R., Wang, C., \& Moody, W. (2000). Salt and pyrophosphate-induced structural changes in myofibrils from chicken red and white muscle. Journal of Science and Food Agriculture, 80(8), 1176-1 182.

Yoon, K. S. (2003). Effect of gamma-irradiation on the texture and microstructure of chicken breast meat. Meat Science, 63(2), 273-277. 


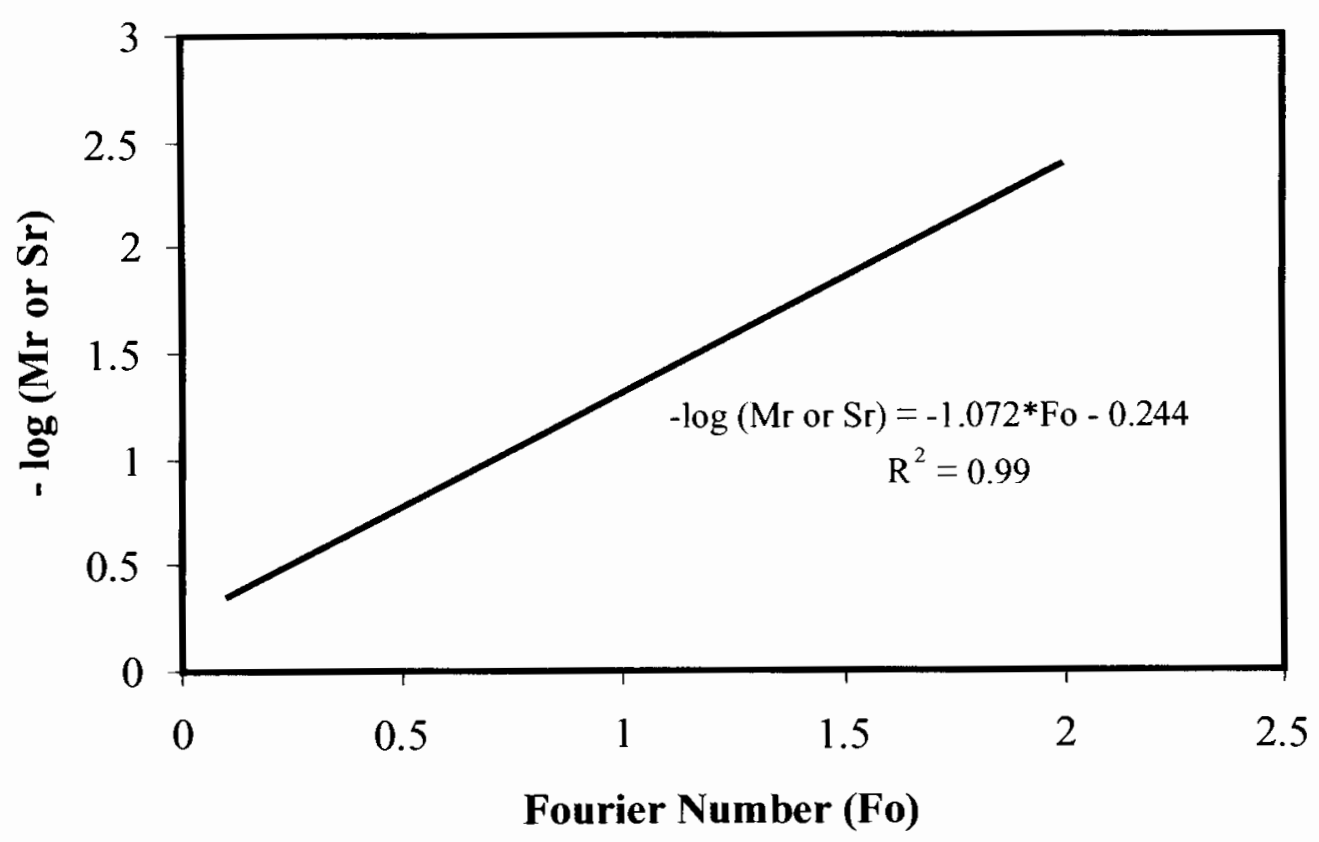

Figure 3.1 Theoretical diffusion curve for cubical configuration as per

Eqs. (3) and (4) 


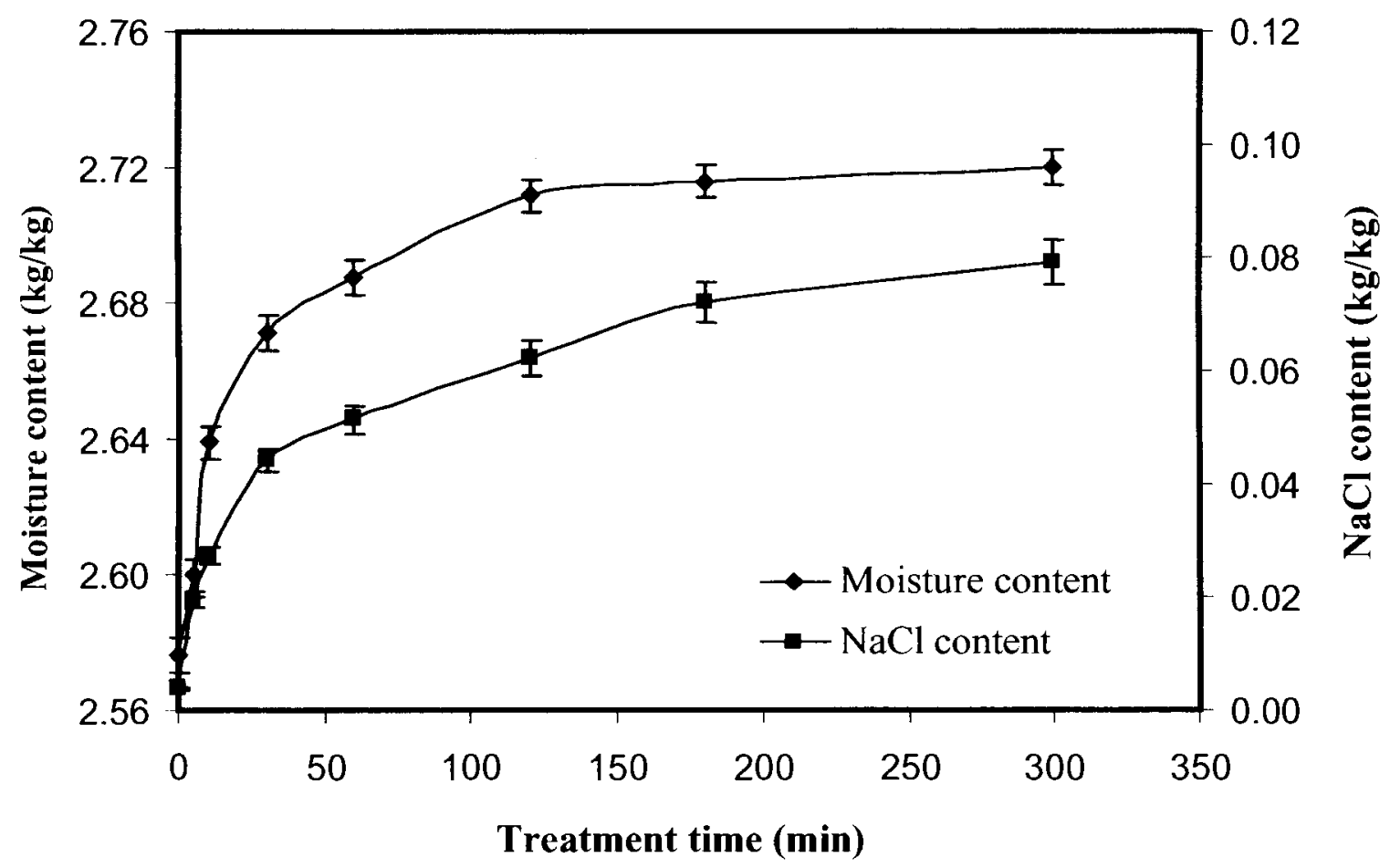

Figure 3.2 Variation of moisture and salt content during salting of turkey breast at atmospheric pressure with treatment time 


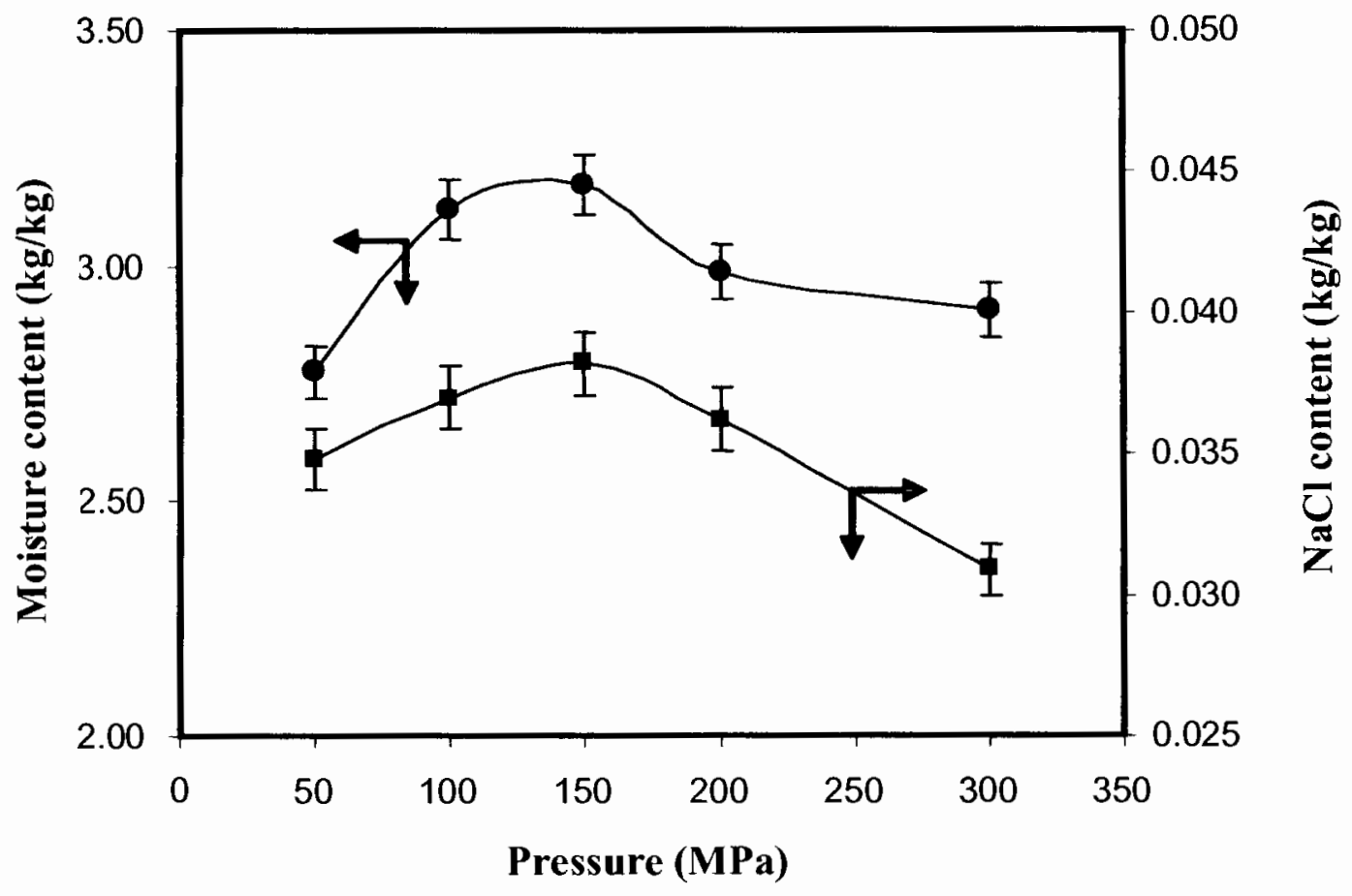

Figure 3.3 Effect of pressure come up time on moisture and $\mathrm{NaCl}$ content during salting of turkey breast at different pressures 

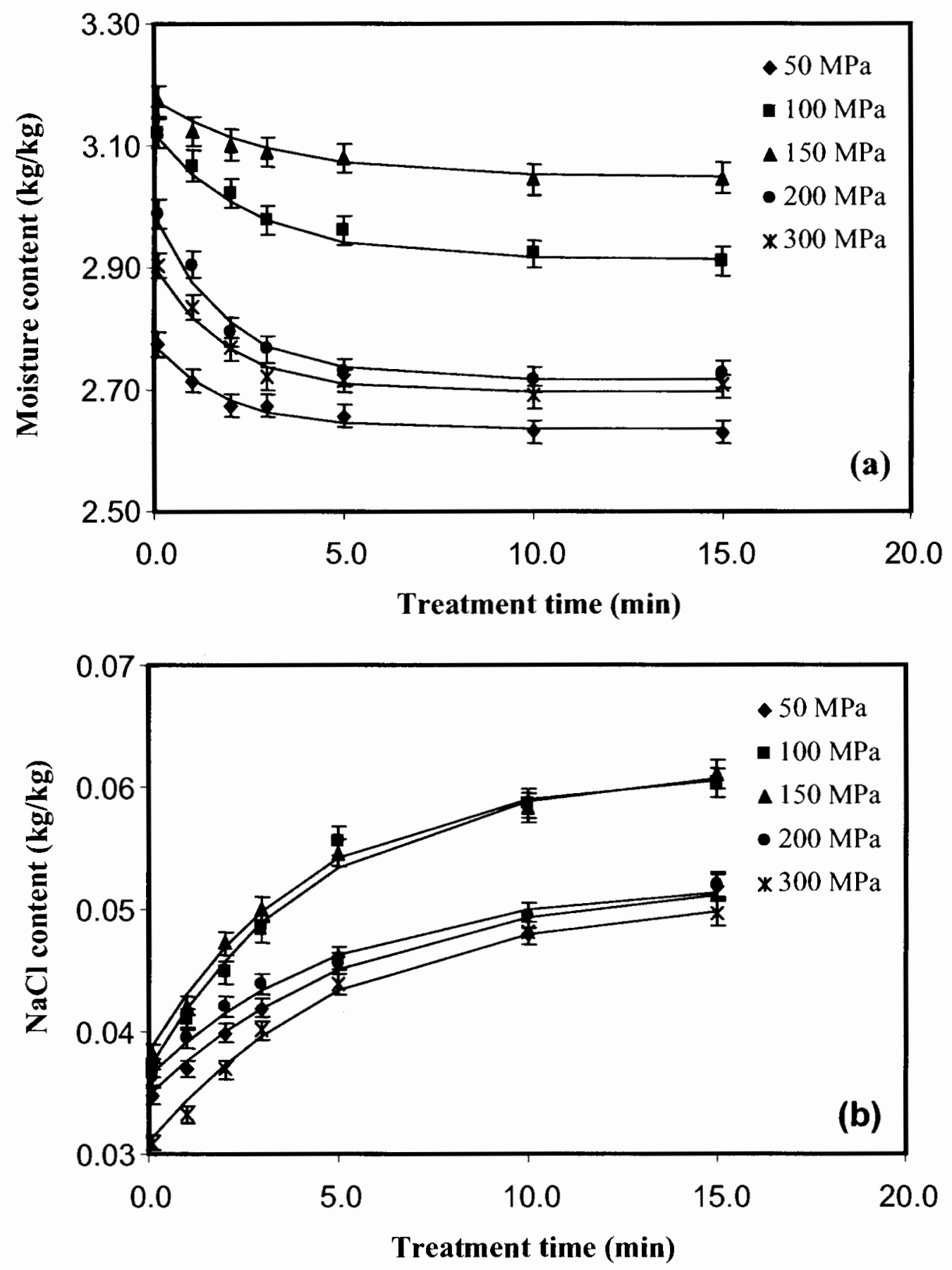

Figure 3.4 Variation of (a) moisture and (b) $\mathrm{NaCl}$ content with holding time during high pressure processing of turkey breast sample. 

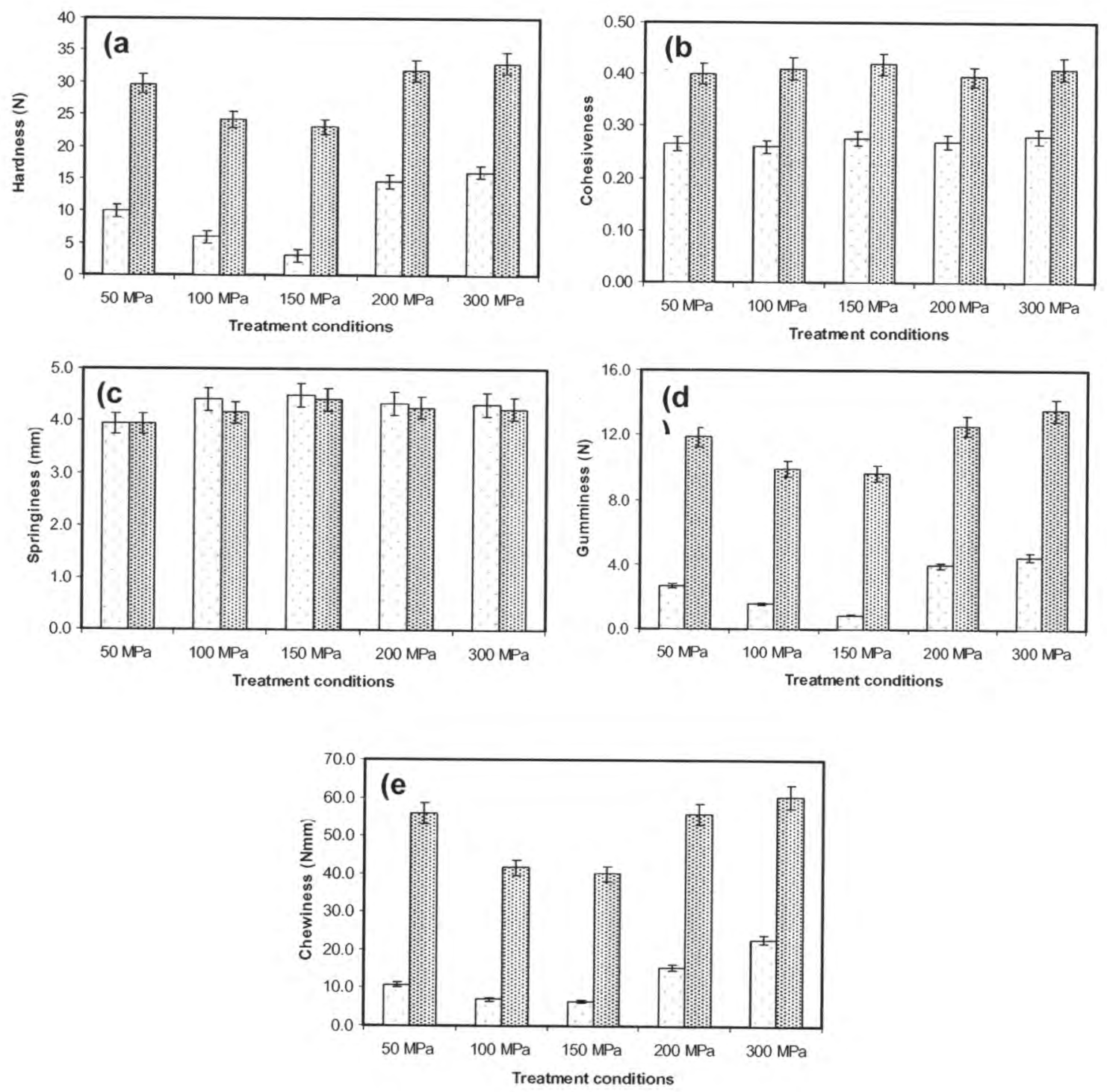

Figure 3.5 Effect of Pressure on (a) hardness, (b) cohesiveness, (c) springiness,

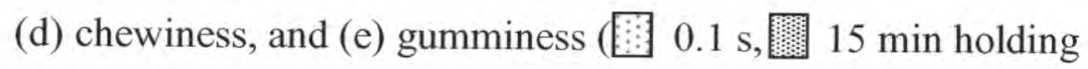
time) 

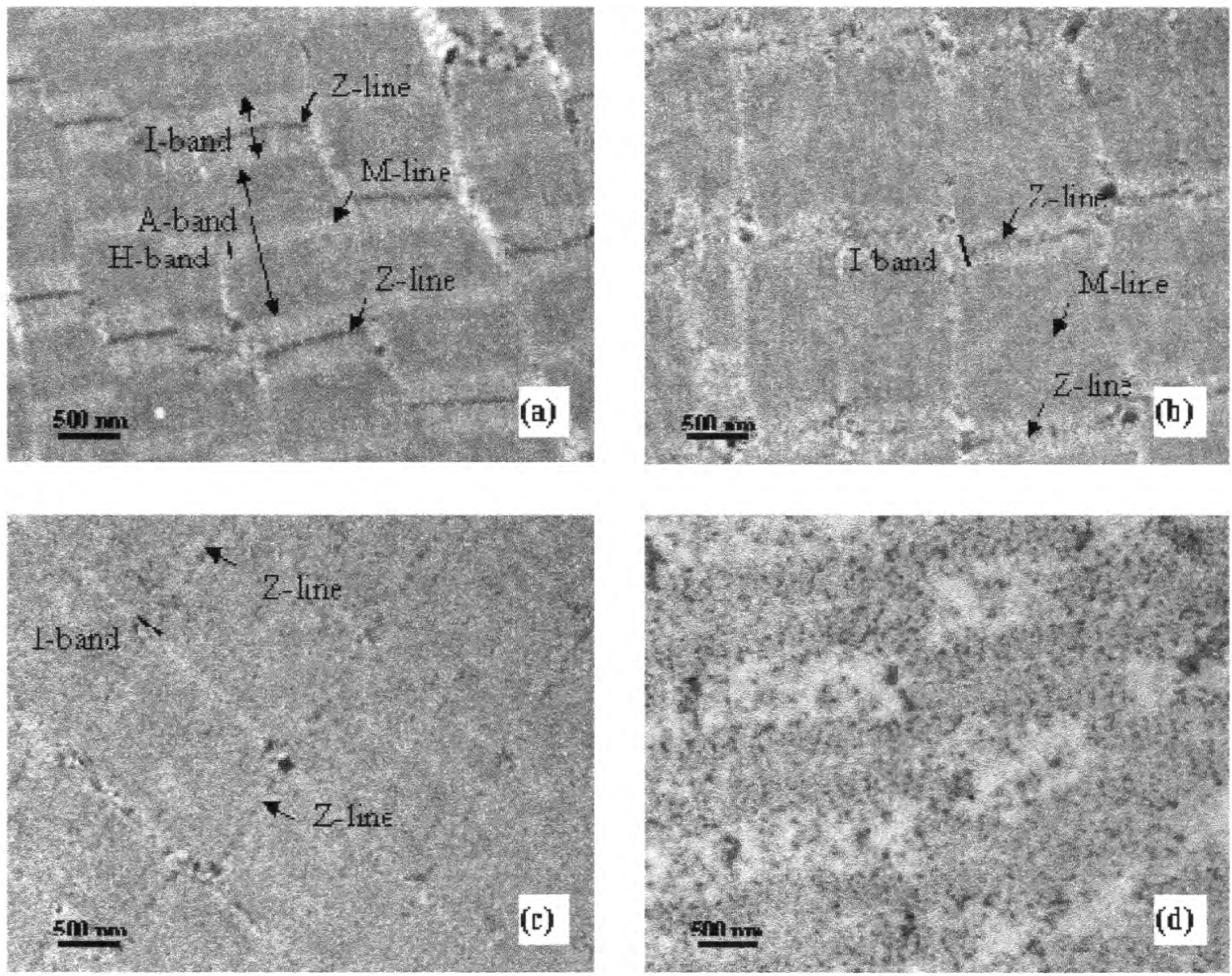

Figure 3.6 TEM of (a) control and pressure treated turkey breast sample during salting at various pressures (b) $0.1 \mathrm{MPa}$, atmospheric pressure; (c) 150 $\mathrm{MPa}$; (d) $300 \mathrm{MPa}$. The samples b, c and d were subjected to $50 \mathrm{~g} / \mathrm{L} \mathrm{NaCl}$ solution. The holding time for the sample subjected to at $0.1 \mathrm{MPa}$ was $2 \mathrm{~h}$ and for other samples was 15 minutes. 


\begin{tabular}{ccccccc}
\hline $\begin{array}{c}\text { Treatment } \\
\text { Pressure } \\
(\mathrm{MPa})\end{array}$ & $\begin{array}{c}\mathrm{D}_{\mathrm{ew}} \times 10^{8} \\
\left(\mathrm{~m}^{2} / \mathrm{s}\right)\end{array}$ & $\begin{array}{c}\mathrm{D}_{\mathrm{es}} \times 10^{8} \\
\left(\mathrm{~m}^{2} / \mathrm{s}\right)\end{array}$ & $\mathrm{k}_{\mathrm{m}}\left(\mathrm{min}^{-1}\right)$ & $\mathrm{k}_{\mathrm{s}}\left(\mathrm{min}^{-1}\right)$ & $\mathrm{m}_{\infty}$ & $\mathrm{s}_{\infty}$ \\
\hline 0.1 & 0.28 & 0.52 & -0.01 & 0.02 & 2.74 & 0.075 \\
50 & 11.89 & 3.85 & 0.53 & 0.17 & 2.64 & 0.053 \\
100 & 8.65 & 5.00 & 0.38 & 0.22 & 2.91 & 0.062 \\
150 & 7.22 & 5.31 & 0.32 & 0.24 & 3.05 & 0.061 \\
200 & 11.77 & 4.52 & 0.52 & 0.20 & 2.72 & 0.052 \\
300 & 11.91 & 4.35 & 0.53 & 0.19 & 2.69 & 0.051 \\
\hline
\end{tabular}

Table 3.1 Effective diffusion coefficients of water $\left(\mathrm{D}_{\mathrm{ew}}\right)$ and $\mathrm{NaCl}\left(\mathrm{D}_{\mathrm{es}}\right)$ at different pressures 


\section{CHAPTER 4}

\section{CONCLUSIONS AND FUTURE RECOMMENDATIONS}

\subsection{Summary and Conclusions}

Within the range of experimental conditions studied, application of high pressures accelerated the diffusion of both water and salt into the turkey breast pieces suspended in $50 \mathrm{~g} / \mathrm{L}$ brine solution, when compared with a similar process carried out at atmospheric pressures. Come up time has an important effect on the final content of $\mathrm{NaCl}$ and water into the turkey breast muscle. During come-up time, both moisture and $\mathrm{NaCl}$ contents increased with an increase in pressure, up to $150 \mathrm{MPa}$.

Holding time also influenced the uptake of salt and water in the turkey meat pieces. An increase in holding time resulted in a higher salt concentration in the sample. On the other hand, water content decreased during extended holding times. Final moisture content of the product was always higher that those values of the untreated sample.

Within the range of experimental conditions studied, maximum salt diffusivity coefficient was obtained at $150 \mathrm{MPa}$. At this same pressure, the effective moisture diffusivity coefficient out of the tissue was the lowest. Further increase in pressure up to $300 \mathrm{MPa}$ produced still higher salt diffusion coefficients than the one at atmospheric pressure. 
Similarly, pressure treatment at $150 \mathrm{MPa}$ significantly influenced the meat textural properties. Hardness, gumminess and chewiness of sample decreased and further influenced by the magnitude of pressure holding time. These textural properties were affected by both the structure of the tissue and the higher concentration of water.

The analysis of the ultrastructure of the tissue under the different treatments improved our knowledge on the impact of the pressure treatment on the meat myofibrils structure. Other than the disappearance of the M-line, no significant change on the myofibril structure was observed when pressure up to $150 \mathrm{MPa}$ was applied. Higher levels of pressure produced the complete destruction of the Z-line and I- band. This might have decreased the diffusion capacity of the tissue.

\subsection{Future Recommendations}

- Effect of HPP on the diffusion of $\mathrm{NaCl}$ and other components at different temperatures.

- Study the influence of pressure treatment on the water holding capacity and texture during storage and after cooking.

- Effect of pressures higher than $300 \mathrm{MPa}$ on the ultrastructure of meat tissues.

- More research is required to understand the muscle protein modifications (solubility, precipitation, denaturation) occurred under high pressures and the presence of salts.

- Utilization of high pressure processing to facilitate the infusion of antioxidant and vitamins in different foods. 
APPENDIX A

MATLAB PROGRAM FOR THE CALCULATION OF $q_{n}$ AND Cn.

(Eqns. (4) \& (5) (Chapter 3). 
Matlab Program for determining the positive roots of $q_{n}$ and $C_{n}$. Values calculated for $n=1: 6$ and $\alpha=6$.

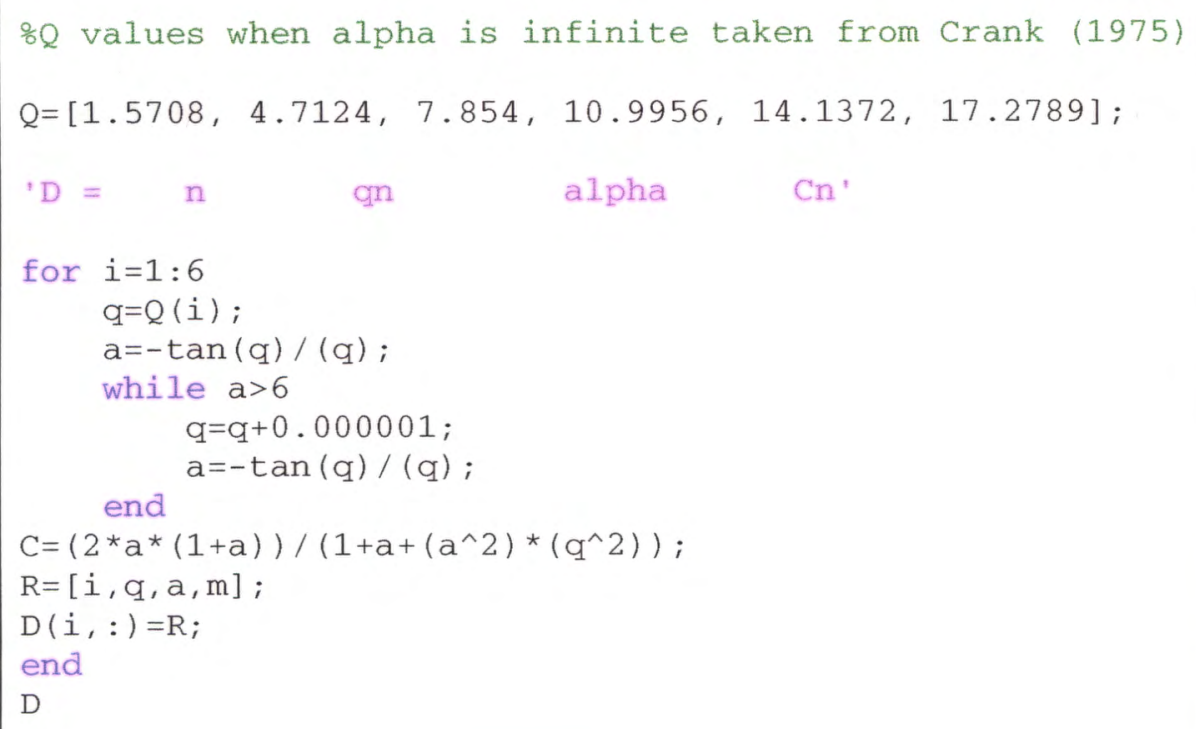

Results in Matlab:

\begin{tabular}{|cccc|}
\hline $\mathrm{n}$ & $\mathrm{qn}$ & alpha & $\mathrm{Cn}$ \\
& & & \\
1.0000 & 1.6703 & 6.0000 & 0.7819 \\
2.0000 & 4.7475 & 6.0000 & 0.1026 \\
3.0000 & 7.8751 & 5.9997 & 0.0375 \\
4.0000 & 11.0107 & 6.0000 & 0.0192 \\
5.0000 & 14.1489 & 5.9999 & 0.0116 \\
6.0000 & 17.2884 & 5.9998 & 0.0078 \\
& & & \\
\hline
\end{tabular}




\section{APPENDIX B}

MATLAB PROGRAM FOR THE CALCULATION OF $m_{\infty}$ or $s_{x_{0}}$ AND $\mathbf{k m}$ or $k_{s}$. 
Matlab Program for the calculation of $M_{\infty}$ or $S_{\infty}$ and $k_{m}$ or $k_{s}$.

Example for calculation of $\mathrm{s}_{\infty}$ and $\mathrm{k}_{\mathrm{s}}$ when pressure $=50 \mathrm{MPa}$

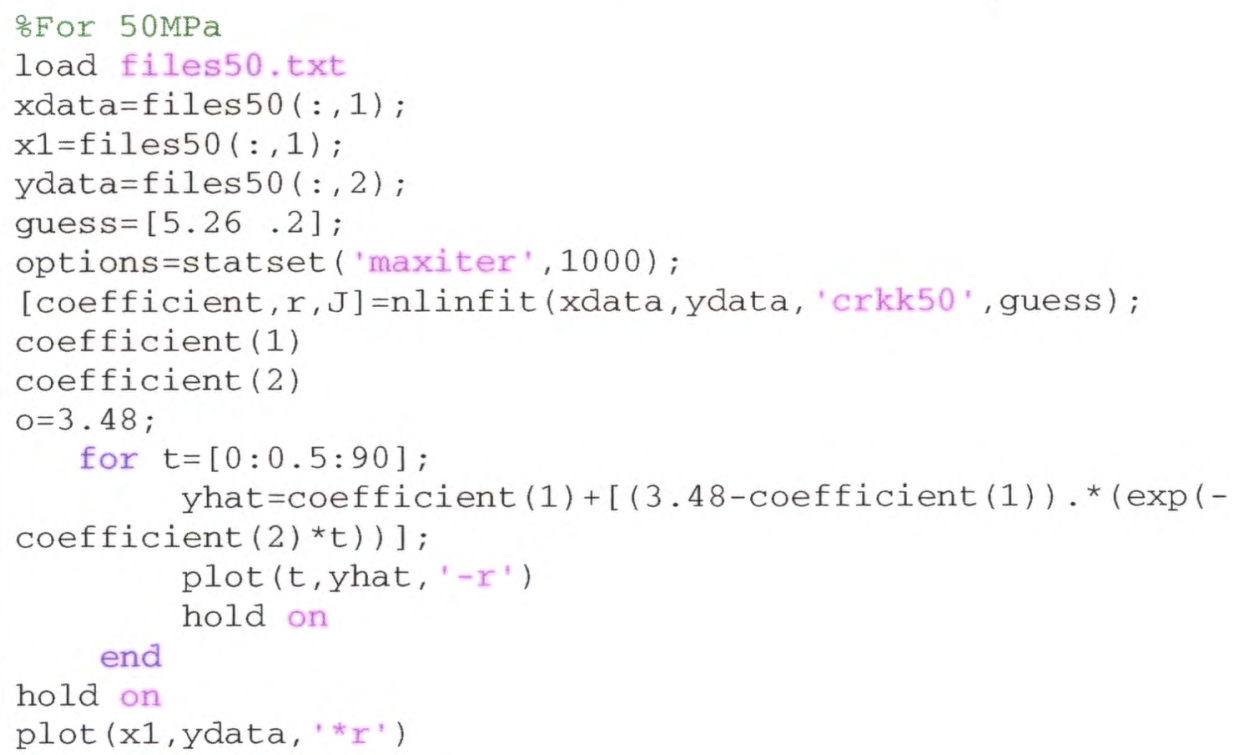

ckk50.m:

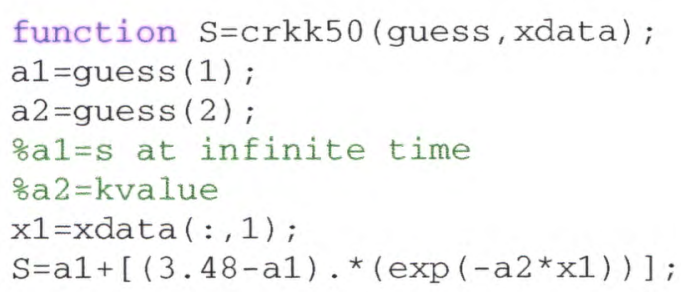

\section{KEY:}

$\mathrm{xdata}=$ data for time ydata $=$ data for salt concentration coefficient $(1)=$ calculated value for salt concentration at infinite time coefficient $(2)=$ calculated value for $\mathrm{k}_{\mathrm{s}}$ $\mathrm{a} 1=$ guessed value for salt concentration at infinitive time $\mathrm{a} 2=$ guessed value for $\mathrm{k}_{\mathrm{s}}$ 
APPENDIX C

TEXTURE PROPERTIES FOR PRESSURE AND NON-PRESSURE TREATED TURKEY BREAST SAMPLES DURING SALTING 


\begin{tabular}{|c|c|c|c|c|c|c|}
\hline \multirow{2}{*}{$\begin{array}{l}\text { Time } \\
(\min )\end{array}$} & \multicolumn{6}{|c|}{ Pressure (MPa) } \\
\hline & 300 & 200 & 150 & 100 & 50 & 0.1 \\
\hline 0.1 & $16.1 \pm 1.5$ & $14.7 \pm 3.3$ & $3.1 \pm 0.2$ & $6.0 \pm 0.54$ & $10.0 \pm 3.1$ & $11.0 \pm 3.5$ \\
\hline 1 & $15.9 \pm 2.9$ & $15.3 \pm 3.7$ & $14.4 \pm 2.0$ & $13.7 \pm 1.92$ & $16.5 \pm 3.4$ & $12.5 \pm 1.9$ \\
\hline 2 & $22.8 \pm 3.1$ & $20.8 \pm 2.5$ & $18.9 \pm 1.1$ & $16.6 \pm 2.62$ & $18.7 \pm 3.2$ & $13.7 \pm 0.2$ \\
\hline 3 & $32.6 \pm 3.0$ & $28.2 \pm 2.2$ & $20.1 \pm 2.5$ & $20.5 \pm 2.68$ & $22.7 \pm 0.9$ & $13.4 \pm 2.8$ \\
\hline 5 & $33.0 \pm 0.9$ & $31.8 \pm 1.8$ & $25.0 \pm 1.2$ & $24.2 \pm 2.38$ & $29.6 \pm 3.1$ & $14.3 \pm 2.2$ \\
\hline
\end{tabular}

Table C.1. Hardness $(\mathrm{N})$ of pressure treated and non-treated $(0.1 \mathrm{MPa})$ turkey breast samples during salting.

\begin{tabular}{ccccccc}
\hline \multirow{2}{*}{$\begin{array}{c}\text { Time } \\
\text { (min) }\end{array}$} & 300 & 200 & 150 & 100 & 50 & 0.1 \\
\hline 0.1 & $4.3 \pm 0.3$ & $4.3 \pm 0.7$ & $4.5 \pm 0.1$ & $4.4 \pm 0.7$ & $4.0 \pm 0.4$ & $3.9 \pm 0.6$ \\
1 & $4.3 \pm 0.7$ & $4.0 \pm 0.8$ & $4.4 \pm 0.8$ & $4.6 \pm 0.6$ & $3.6 \pm 0.4$ & $3.9 \pm 0.3$ \\
2 & $4.6 \pm 0.8$ & $4.7 \pm 0.1$ & $4.5 \pm 0.1$ & $4.5 \pm 0.3$ & $4.3 \pm 0.6$ & $3.7 \pm 0.3$ \\
3 & $4.3 \pm 0.4$ & $4.5 \pm 0.8$ & $4.4 \pm 0.1$ & $4.5 \pm 0.7$ & $4.0 \pm 0.7$ & $3.7 \pm 0.1$ \\
5 & $4.2 \pm 0.6$ & $4.3 \pm 0.1$ & $4.4 \pm 0.3$ & $4.2 \pm 0.6$ & $3.9 \pm 0.3$ & $3.9 \pm 0.3$ \\
\hline
\end{tabular}

Table C.2. Springiness $(\mathrm{mm})$ of pressure treated and non-treated ( $0.1 \mathrm{MPa})$ turkey breast samples during salting. 


\begin{tabular}{lllllll}
\hline \multirow{2}{*}{$\begin{array}{l}\text { Time } \\
(\mathrm{min})\end{array}$} & \multicolumn{5}{c}{ Pressure } \\
\cline { 2 - 7 } & $300 \mathrm{MPa}$ & $200 \mathrm{MPa}$ & $150 \mathrm{MPa}$ & $100 \mathrm{MPa}$ & $50 \mathrm{MPa}$ & $0.1 \mathrm{MPa}$ \\
\hline 0.1 & $0.28 \pm 0.06$ & $0.28 \pm 0.02$ & $0.28 \pm 0.01$ & $0.26 \pm 0.04$ & $0.27 \pm 0.08$ & $0.34 \pm 0.04$ \\
1 & $0.34 \pm 0.08$ & $0.32 \pm 0.03$ & $0.39 \pm 0.03$ & $0.38 \pm 0.04$ & $0.34 \pm 0.03$ & $0.35 \pm 0.03$ \\
2 & $0.35 \pm 0.02$ & $0.37 \pm 0.04$ & $0.41 \pm 0.02$ & $0.38 \pm 0.02$ & $0.41 \pm 0.03$ & $0.35 \pm 0.08$ \\
3 & $0.42 \pm 0.05$ & $0.40 \pm 0.04$ & $0.41 \pm 0.03$ & $0.39 \pm 0.01$ & $0.39 \pm 0.01$ & $0.31 \pm 0.06$ \\
5 & $0.41 \pm 0.02$ & $0.40 \pm 0.06$ & $0.42 \pm 0.03$ & $0.41 \pm 0.05$ & $0.40 \pm 0.03$ & $0.34 \pm 0.07$ \\
\hline
\end{tabular}

Table C.3. Cohesiveness of pressure treated and non-treated ( $0.1 \mathrm{MPa})$ turkey breast samples during salting.

\begin{tabular}{|c|c|c|c|c|c|c|}
\hline \multirow{2}{*}{$\begin{array}{l}\text { Time } \\
(\min )\end{array}$} & \multicolumn{6}{|c|}{ Pressure } \\
\hline & $300 \mathrm{MPa}$ & $200 \mathrm{MPa}$ & $150 \mathrm{MPa}$ & $100 \mathrm{MPa}$ & $50 \mathrm{MPa}$ & $0.1 \mathrm{MPa}$ \\
\hline 0.1 & $22.8 \pm 4.6$ & $15.4 \pm 5.3$ & $6.5 \pm 1.0$ & $6.9 \pm 1.1$ & $10.7 \pm 5.2$ & $14.4 \pm 3.2$ \\
\hline 1 & $25.0 \pm 5.0$ & $19.6 \pm 2.3$ & $25.1 \pm 3.2$ & $25.9 \pm 0.9$ & $25.0 \pm 2.7$ & $17.5 \pm 3.7$ \\
\hline 2 & $37.1 \pm 5.8$ & $36.9 \pm 1.9$ & $31.6 \pm 9.1$ & $33.9 \pm 1.6$ & $33.0 \pm 4.3$ & $18.2 \pm 4.3$ \\
\hline 3 & $57.0 \pm 3.7$ & $51.2 \pm 2.1$ & $31.4 \pm 6.6$ & $38.8 \pm 4.8$ & $35.7 \pm 4.9$ & $16.0 \pm 2.3$ \\
\hline 5 & $60.4 \pm 5.7$ & $55.8 \pm 2.6$ & $40.1 \pm 0.6$ & $41.6 \pm 3.2$ & $55.8 \pm 4.8$ & $19.3 \pm 5.3$ \\
\hline
\end{tabular}

Table C.4. Chewiness $(\mathrm{Nmm})$ of pressure treated and non-treated (0.1 $\mathrm{MPa})$ turkey breast samples during salting. 


\begin{tabular}{ccccccc}
\hline \multirow{2}{*}{$\begin{array}{c}\text { Time } \\
(\mathrm{min})\end{array}$} & \multicolumn{6}{c}{ Pressure } \\
\cline { 2 - 7 } & $300 \mathrm{MPa}$ & $200 \mathrm{MPa}$ & $150 \mathrm{MPa}$ & $100 \mathrm{MPa}$ & $50 \mathrm{MPa}$ & $0.1 \mathrm{MPa}$ \\
\hline 0.1 & $4.6 \pm 0.4$ & $4.0 \pm 1.0$ & $0.9 \pm 0.1$ & $1.6 \pm 0.4$ & $2.7 \pm 1.6$ & $3.6 \pm 1.5$ \\
1 & $5.8 \pm 2.2$ & $4.8 \pm 1.4$ & $5.6 \pm 1.6$ & $5.2 \pm 0.9$ & $5.5 \pm 0.7$ & $4.4 \pm 0.9$ \\
2 & $8.1 \pm 1.3$ & $7.9 \pm 0.3$ & $7.8 \pm 0.4$ & $6.3 \pm 1.1$ & $7.5 \pm 1.8$ & $4.9 \pm 1.0$ \\
3 & $13.2 \pm 0.7$ & $11.4 \pm 1.4$ & $8.1 \pm 0.9$ & $7.9 \pm 1.2$ & $8.8 \pm 0.2$ & $4.3 \pm 0.5$ \\
5 & $13.5 \pm 0.5$ & $12.6 \pm 1.3$ & $9.5 \pm 1.1$ & $9.6 \pm 1.7$ & $11.7 \pm 1.2$ & $5.0 \pm 1.7$ \\
\hline
\end{tabular}

Table C.5. Guminess $(\mathrm{N})$ of pressure treated and non-treated $(0.1 \mathrm{MPa})$ turkey breast samples during salting. 
APPENDIX D

SAS SYNTAX 


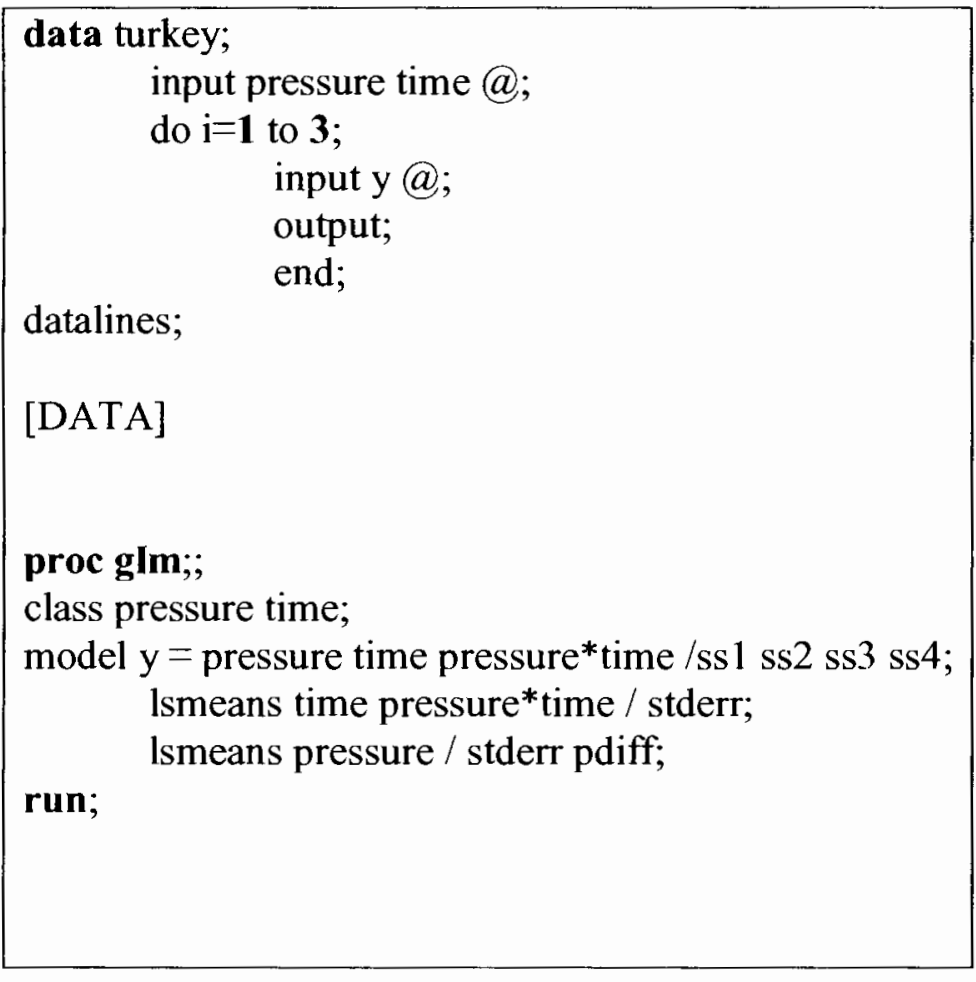

\section{KEY}

Pressure - refers to pressure conditions such as $100 \mathrm{MPa}$ time - refers to the pressure holding time such as $0.1 \mathrm{sec}$ $\mathrm{i}$ - refers to the number of replicates 
APPENDIX E

TEM OF PRESSURE TREATED TURKEY BREAST SAMPLES 

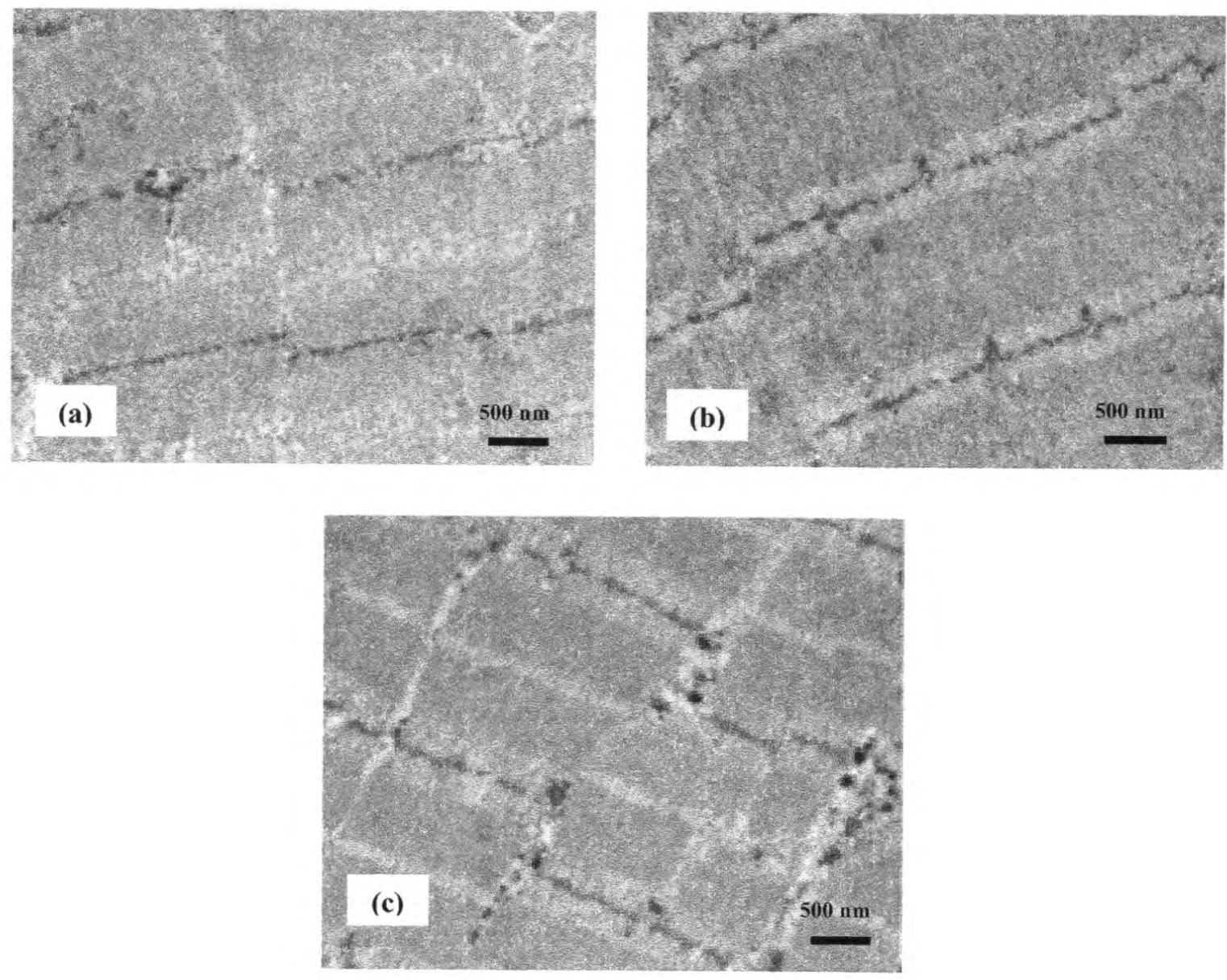

Figure E.1 TEM pressure treated turkey breast sample during salting at (a) $150 \mathrm{MPa}$ for 0.1 seconds, (b) $300 \mathrm{MPa}$ for 0.1 seconds. (c) Pressure treated turkey breast without salting at $150 \mathrm{MPa}$ for 15 minutes. 


\section{BIBLIOGRAPHY}

Ahromrit, A., Ledward, D., \& Niranjan, K. (2006). High pressure induced water uptake characteristics of Thai glutinous rice. Journal of Food Engineering, 72, 225-233.

Aktas, N. Aksu, M., \& Kaya, M. (2003). The influence of marination with different salt concentrations on the tenderness, water holding capacity and bound water content of beef. Turkish Journal of Veterinary and Animal Science. 27, 1207- 1211.

Angsupanich K., Edde, M., \& Ledward, D. A. (1999). Effects of High Pressure on the Myofibrillar Proteins of Cod and Turkey Muscle. Journal of Agricultural and Food Chemistry, 47(1), 92-99.

Balasubramaniam, S., \& Balasubramaniam. V. M. (2003). Compression heating influence of pressure transmitting fluids on bacteria inactivation during high pressure processing. Food Research International, 36(7), $661-668$.

Barbout, S. (2002). Poultry Products Processing, An Industry Guide. CRC Press, 202, 254-256.

Bouton, P.E., Ford, A. L., Harris, P.V., Macfarlane, J.J. \& O'Shea, J.M. (1977). Pressureheat treatment of post rigor muscle: Effects on tenderness. Journal of Food Science, 42,132 .

Cheftel J. C., \& Culioli J. (1997). Effects of high pressure on meat: a review. Meat Science, 46(3), 211-36.

Crank, J. (1975). The mathematics of diffusion. Oxford: Clarendon Press.

Deumier, F., Trystram, G., Collignan, Guedider, L. \& Bohuon, P. (2003). Pulsed vacuum brining of poultry meat: interpretation of mass transfer mechanisms. Journal of Food Science, 58(1), 85-93.

Earnshaw, R. (1996). High pressure food processing. Nutrition \& Food Service, 2, 8-1 1.

Gou, P., Comaposada, J. \& Arnau, J. (2004). Moisture diffusivity in the lean tissue of dry-cured ham at different process times. Meat Science, 67, 203-209. 
Gou, P., Comaposada, J. \& Arnau, J. (2003). NaCl content and temperature effects on moisture diffusivity in the Gluteus medium muscle of pork ham. Meat Science. 63, $29-34$.

Graiver, N., Pinotti, A., Califano, A., \& Zaritzky, N. (2006). Diffusion of sodium chloride in pork tissue. Journal of Food Engineering, 77, 910-918.

Harris, P. \& Shorthose, W. (1988). -In Developments in Meat Science, Vol 4, ed. Lawrie L. A., Elsevier Appl. Sci. Publ., London, chapter 5.

Jimenez Colmenero, F. (2002). Muscle protein gelation by combined use of high pressure/temperature. Trend in Food Science and Technology, 13(1), 22-30.

Jimenez-Colmenero F., Fernandez, P., Carballo, J., \& Fernandez-Martin F. (1998). Highpressure-cooked Low-fat pork and chicken batters as affected by salt levels and cooking temperature. Journal of Food Science, 63, 656-659.

Kamiyama, K., Ikeuchi, Y., Suzuki, A., Kim, K., Hayashi, T., \& lto, T. (2001). An Inmunological Assessment of Myosin Degradation in Pressurized Chicken Muscle. Journal of Food Science, 66, 1126-1129.

Knorr, D. (1999). Novel approaches in food-processing technology: new technologies for preserving foods and modifying function. Current opinion in Biotechnology, 10(5), 485-491.

Lerici, C. R., Pinnavaia, G., Dalla Rosa, M., \& Bartolucci, L. (1985). Osmotic dehydration of fruit: Influence of osmotic agents on drying behavior and product quality. Journal of Food Science, 50, $1217-1219$.

Kim, K., Ikeuchi, Y., \& Suzuki, A. (1992). Pressure-induced conversion of $\alpha$-connectin to $\beta$-connectin. Meat Science, 32, 243-243.

Ma, H., \& Ledward, D. (2004). High pressure/thermal treatment effects on the texture of beef muscle. Meat Science, 68, 347-355.

Macfarlane, J.J. (1973). Pre-rigor pressurization of muscle: Effects on pH, shear value and taste panel assessment, Journal of Food Science, 38, 294-298.

Macfarlane, J.J. (1974). Pressure-lnduced Solubilization of Meat Proteins in Saline Solution. Journal of Food Science, 39, 542-547.

Macfarlane, J.J., Mckenzie I.J. (1976). Pressure-Induced Solubilization of Myofibrillar Proteins. Journal of Food Science, 41, 1442-1446. 
Macfarlane, J. J., Turner, R. H., \& Ratcliff, D. (1976). Comparison of the effects of prerigor cold and pressure treatments on some properties of beef biceps muscle. Journal of Food Science, 41, 1447.

Macfarlane, J.J., Mckenzie I.J., Turner R.H. (1980). Pressure treatment of meat: Effects on thermal transitions and shear values, Meat Science, 5, 307-317.

Macfarlane, J. J. \& Morton, D. J. (1978). Effect of pressure treatment on the ultra structure of striated muscle. Meat Science, 2, 281-288.

Mandava, R., Fernandez, I., and Juillerat, M. 1994. Effect of high hydrostatic pressure on sausage batters. Proceedings of 40th International Congress of Meat Science and Technology. S-VIB. 11, 1-6. The Hague, Holland.

Nicoletti, V. Romanelli, P., Gabas, A., \& Romero, J. (2003). Salting kinetics and salt diffusivities in farmed Pantanal caiman muscle. Pesq. agropec. bras., v. 38, 4, 529 535.

Offer, G., \& Knight, P. (1988). -In Developments in Meat Science, Vol 4, ed. Lawrie L. A., Elsevier Appl. Sci. Publ., London, chapters 3 \&4.

Offer, G., \& Trinick, J. (1983). On the mechanism of water holding in meat: the swelling and shrinking of myofibrils. Meat Science, 8, 245-281.

Oztan, A., \& Mehmet, M. (2005) Mass transfer through meat. Part I. Determination of diffusion coefficient of nitrite by time lag method. Journal of Food Engineering, $67,387-391$.

Pinotti, A., Graiver, N., Califano, A., \& Zaritzky, N. (2001). Diffusion of nitrite and nitrate salts in pork tissue in the presence of sodium chloride. Journal of Food Science. 67, 2165-2171.

Polydera, A. C., Stoforos, N. G., \& Taoukisn P. S. (2003). Comparative shelf life study and vitamin $\mathrm{C}$ loss kinetics in pasteurized and high pressure processed reconstituted orange juice. Journal of Food Engineering, 60(1), 21-29.

Ramaswamy, R., Balasubramaniam, V. M., \& Sastry, S. K. (2005). Effect of high pressure and irradiation treatments on hydration characteristics of Navy beans. International Journal of Food Engineering, Vol 1(4), Art 3.

Ramirez-Suarez, J. C., \& Morrisey, M. T. (2006) Effect of high pressure processing (HPP) on shelf life of albacore tuna (Thunnus alalunga) minced muscle. Innovative Food Science and Emerging Technologies, 7(1-2), 19-27. 
Rastogi, N., \& Niranjan, K. (1998). Enhanced mass transfer during osmotic dehydration of high pressure processed treated pineapple. Journal of Food Science, 63(3), 508 511.

Rastogi, N. K., Esthiaghi, M. N., \& Knorr, D. (1999). Accelerated mass transfer during osmotic dehydration of high intensity electrical field pulse pretreated carrots, Journal of Food Science, 64, 1020- 1023.

Rastogi, N. K., Angersbach, A., Niranjan, K., \& Knorr, D. (2000). Rehydration kinetics of high pressure treated and osmotically dehydrated pineapple. Journal of Food Science, 65, 838-841.

Rastogi, N. K., Raghavarao, K. S. M. S., Niranjan, K., \& Knorr, D. (2002). Recent developments in osmotic dehydration: methods to enhance mass transfer. Trends in Food Science and Technology, 13, 48 - 59.

Rastogi, N. K., \& Raghavarao, K. S. M. S. (2004). Mass transfer during osmotic dehydration of pineapple: considering Fickian diffusion in cubical configuration. Lebensmittel Wissenschaft und Technologie, 37, $43-47$.

Rastogi, N.K., K.S.M.S. Raghavarao, V.M. Balasubramaniam, Niranjan, K. and Knorr, D. (2006). Opportunities and challenges in high pressure processing of foods. Critical Reviews in Food Science and Nutrition (In press).

Simal, S, Sanchez, E. S., Bon, J, Femenia, A, Rossello, C. (2001). Water and salt diffusion during cheese ripening: effect of the external and internal resistances to mass transfer. Journal of Food Engineering, 48(3), 269 - 275.

Singh, B., \& Gupta, A. K. (2006) Mass transfer kinetics and determination of effective diffusivity during convective dehydration of pre-osmosed carrot cubes. Journal of Food Engineering (In press).

Singh, P., Heldman, D. (2001). Introduction to Food Engineering. $3^{\text {rd }}$ edition. London: Academic Press.

Smith, D. (2001). Functional properties of muscle proteins in processed poultry products. In A. Sams, Poultry meat processing. (pp.181-194). CRC Press.

Sopanangkul, A., Ledward, D., \& Niranjan, K. (2002) Mass transfer during sucrose infusion into potatoes under high pressure. Journal of Food Science, 67(6), 2217 2220 . 
Suzuki, A., Watanabe, M., Iwamura K., Ikeuchi, Y., \& Saito, M. (1990). Effect of high pressure treatment on the ultra-structure and myofibrillar protein of beef skeletal muscle. Agricultural and Biological Chemistry, 54(12), 3085-3091.

Suzuki, A., Suzuki, N., Ikeuchi, Y., \& Saito, M. (1991). Effects of high pressure treatment on the ultrastructure and solubilization of isolated myofibrils. Agricultural and Biological Chemistry, 55(10), 2467-2473.

Suzuki, A., Kim, K., Tanji, H., \& Ikeuchi, Y. (1998). Effects of high hydrostatic pressure on postmortem muscle. Recent Research Development in Agricultural \& Biological Chemistry, 2, 307-331.

Suzuki, Q., Homma, Y., Kim, K., Ikeuchi, Y., Sugiyama, T., \& Saito, M. (2001). Pressure-induced changes in the connectin/titin localization in the myofibrils revealed by immunoelectron microscopy. Meat Science, 59, 193-197.

Unal, S., Erdoghdu, F., Ekiz, H., \& Ozdemir, Y. (2004). Experimental theory, Fundamentals and mathematical evaluation of phosphate diffusion in meats. Journal of Food Engineering, 65, $263-272$.

Wang, W., \& Sastry, S. (1993). Salt diffusion into vegetable tissue as a pretreatment for ohmic heating: Determination of parameters and mathematical model verification. Journal of Food Engineering, 20, 311-323.

Wang, D., Tang, J., \& Correa L. (2000). Salt diffusivities and salt diffusion in farmed Atlantic salmon muscle as influenced by rigor mortis. Journal of Food Engineering, $43,115-123$.

Xiong, Y., \& Kupski, R. (1999). Monitoring phosphate marinade penetration in tumbled chicken filets using a thin-slicing, dye-tracing method. Journal of Poultry Science, $78,1048-1052$.

Zamri, A., Ledward, D., \& Frazier, R. (2006). Effect of combined heat and high-pressure treatments on the texture of chicken breast muscle (Pectoralis Fundus). Journal of Agricultural Food Chemistry, 54, 2992-2996. 